\title{
"... säveltäjän perimmäinen tarkoitus ei liene järkyttää.'" Lähtökohtia 1960-luvun alun musiikkiradikalismin tarkasteluun
}

\begin{abstract}
Ylipäänsä tuntui, että tilanne, jossa näennäiset tosiseikat asetetaan päälaelleen on aina terveellinen, koska silloin ihminen joutuu kysymään itseltään kysymyksiä siitä, onko se mikä näyttää todelta, onko se todella totta. (Otto Donner, haastattelu 1994.)
\end{abstract}

Minä olin sodan ajan lottana ja kun oli käynyt läpi kaiken sen ja jäänyt vielä elämään, niin kaiken käskyjen ja järjestyksen jälkeen ainoa todellisuus oli absurdi käsitys maailmasta. - - absurdius jossa haettiin todellisuudet todellisuuden takaa. (Vivica Bandler, haastattelu 1994.)

Uutta musiikkia koskevassa keskustelussa näyttää aika ajoin tulevan esiin teema, joka koskee uuden musiikin tehtävää. Keskeinen ajatus on puettu tuolloin kysymykseen, pitääkö säveltäjän '"kohahduttaa". Ajatus uudesta musiikista suunnannäyttäjänä ja uuden etsijänä, joka ei tavoita suurta yleisöä eikä aina edes valistuneintakaan kuuntelijakuntaa, on varmasti yksi taidemusiikin kentän keskeisistä piirteistä. Suomalaisessa keskustelussa kysymys kuulijakunnan "kohahduttamisesta" juontaa juurensa vahvasti 1960-luvun alkuvuosiin. Huomiota herätti tuolloin ryhmä nuoria säveltäjiä ja kriitikoita, jotka toimivat Suomen Musiikkinuoriso -yhdistyksen nimissä. Ryhmä muistetaan radikaalista nykymusiikkipolemiikistaan ja ns. "lastenkamarikonserttien" järjestämisestä. Lisäksi 1960-luvun puolivälissä osa ryhmän säveltäjistä ja kriitikoista osallistui aktiivisesti populaarimusiikista käytyyn keskusteluun, jolloin heidän estetiikka-näkemyksensä saivat aikaan varsin värikkäitä kannanottoja. Samalla se kasvatti rintamalinjoja, joiden käsitykset niin musiikin estetiikasta kuin musiikin asemasta ja tehtävistä poikkesivat jyrkästi toisistaan. Sarjallisuuden reaktioilmiöissä nuori säveltäjäpolvi kulki 1960-luvun alussa lähes samassa tahdissa eurooppalaisten esikuviensa kanssa. Mutta ehkä enemmän kuin itse musiikkiin, on jälkeenpäin kiinnitetty huomiota ryhmän toimintatapoihin: "nuorten vihaisten miesten" toiminta on tulkittu osana 60-lukulaista sukupolvikonfliktia. (Esim. Tuominen 1992.) Poikkeuksena on Heiniön (1988) teos, jossa hän soveltaa postmodernin käsitettä 1960-luvun jälkeen syntyneeseen suomalaiseen musiikkiin. Tässä artikkelis- 
sa pyrin luomaan eräänlaista synteesiä näiden kahden näkökulman välille, vaikka en sinänsä ota kantaa postmodernia koskevaan keskusteluun. Pikemminkin pyrin asettamaan Suomen Musiikkinuorison piirissä toimineiden "radikaalien" säveltäjien - tässä artikkelissa esimerkkinä ovat Henrik Otto Donner ja Kari Rydman - toiminnan laajemmin historialliseen kontekstiin. Keskeiselle sijalle musiikin tarkastelussa nousee tällöin se, millaisille urille uutta musiikkia koskeva ajattelu kulki sarjallisuuden reaktioilmiöissä ja mihin nämä ajatukset johtivat. Toinen tarkastelunäkökulma on peräisin taiteensosiologiasta. Sen avulla pyrin hahmottamaan suomalaisen taidemusiikin historiallista kehitystä ja sen asemaa suhteessa muihin taiteisiin ja ympäröivään yhteiskuntaan 1960-luvun alussa.

\section{Taide ja moderni yhteiskunta}

Keskusteltaessa niin taidemusiikin kuin taiteen tutkimuksesta yleensä kiistoja herättää usein kysymys taiteen autonomisuudesta: onko mahdollista tutkia taidetta itsemääräytyvänä vai tuleeko sen ympäristö, konteksti, ottaa huomioon ja miten. Autonomiaa puolustava näkökulma on ollut taiteiden tutkimuksessa varsin pitkään vallalla. Erityisesti taiteensosiologit ovat kritisoineet tätä ns. autonomiateoriaa, jonka seurauksena on katsottu, että sosiologit eivät voi tutkia taidetta, koska "aito" taide on yhteiskunnasta riippumatonta. Tällöin on katsottu, että kunkin taidealan erityistieteiden formaaliset ja hermeneuttiset menetelmät ovat legitiimejä taiteen tutkimiseksi. (Sevänen 1991b, 296298) Taidemusiikin tutkimuksessa autonomiateoria on sisältynyt tutkimukseen myös eksplisiittisesti. Tähän on nähty olevan historialliset perusteensa: 1800-luvulta alkaen taidemusiikin piirissä autonomista musiikkia on pidetty arvokkaana, funktionaalista triviaalina. Esimerkiksi Mäkelän mukaan (1990, 7-8) suhtautumistapa johtuu Beethoven -reseptiosta, jonka myötä esityskeskeisyys alkoi väistyä teoskeskeisyyden tieltä: yksilöllisestä esittävästä taiteilijasta tuli tulkitsija, teoksista tulkittavia "tekstejä" ja improvisaatio tai täydentävä improvisaatio julistettiin pannaan. Toisaalta esimerkiksi Heiniö (1992, 13-14) näkee tarkastelutavan johtuvan käytännön syistä: tutkimuksessa painotetaan usein sitä, että ilmiön sisäiset ominaisuudet on analysoitava ensin perusteellisesti ennen kuin voidaan tarkastella ilmiön suhdetta ympäristöönsä.

Etnomusikologian ja perinteisen musiikkitieteen näkökulmien ero palautuu viime kädessä kysymykseen tutkimuskohteen autonomisuudesta: tutkiako musiikkia omalakisena vai osana kulttuuria ja kulttuurin heijastajana. Tosin nykytutkimus on ottanut tieteenalojen luonteen, erot ja ongelmat keskustelun kohteeksi (esim. Heiniö 1992, Kurkela 1991) ja joko/tai -vaihtoehtojen rinnalle ollaan etsimässä välittäviä näkökulmia. Lisäksi viime aikoina erityisesti sukupuolistava musiikintutkimus ja feministinen kritisismi ovat tuoneet mukanaan 
tuoreita tutkimusnäkökulmia ja analyysitapoja taidemusiikin tutkimukseen (esim. Moisala 1994 ja Richardson 1994). Oma tutkimusongelmani on syntynyt kuitenkin pääasiassa taiteensosiologisissa tutkimuksissa käytettyjen lähestymistapojen myötä (esim. Lepistö 1991, Sevänen 1994), joissa keskeisenä lähtökohtana on ollut modernin yhteiskunnan taidejärjestelmien historiallinen tarkastelu.

Kysymykseen musiikin autonomiasta ja itsenäisyydestä olen ottanut tässä artikkelissa välittävän kannan: tarkastelen musiikkia sekä autonomisena että suhteessa ympäröivään yhteiskuntaan ja myös muihin taide- ja musiikinlajeihin. Kysymys ei kuitenkaan ole "ongelmanratkaisusta", vaan pikemminkin sen ongelmakentän hahmottamisesta tutkimuksessa, joka koskee taidemusiikkia ja sen asemaa modernissa yhteiskunnassa.

\section{Taidemaailma}

Lähtökohtanani on näkemys siitä, että modernissa yhteiskunnassa taide on eriytynyt omaksi alueekseen. Ajatus liittyy keskeisesti ns. modernisaatioteorioihin, joissa modernisaation on nähty merkinneen sosiaalisten järjestelmien eriytymistä ja niiden omalakisuuden kasvua. ${ }^{1}$ Historiallisesti taiteen eriytymisen katsotaan alkaneen 1700-luvulla, jolloin uskonnollisten, poliittisten ja moraalisten normien tilalle alkoivat nousta esteettiset normit taiteen arviointikriteereinä. Taustalla olivat niin renessanssin individualistinen ihmiskuva kuin porvarillisen liberalismin myötä 1700- ja 1800-luvuilla syntynyt romanttinen estetiikka. Nämä loivat näkemystä siitä, että taiteilija on sosiaalisista rakenteista vapaa ja synnyttivät vähitellen käsityksen taiteen autonomiasta ja toisaalta myös taiteen autonomiateorian. Taideteosten autonomisuuden lisäksi autonomiateoriassa on korostettu sitä, että taiteelta puuttuu yhteiskunnallinen funktio. Tämän on nähty johtuvan siitä, että taiteelle annettiin tehtäväksi ilmaista täydellisinä ne porvariston nousuun kytkeytyvät emansipatoriset ihanteet, jotka eivät toteutuneet vallitsevassa yhteiskunnassa. Porvarilliseksi muuttuvalle yhteiskunnalle varjopuolineen taide tarjosi mahdollisuuden vaalia humanistisia ihanteita. Pyrkimys pois yhteiskunnasta ja sen elämänkäytännöistä oli kuitenkin kasvualusta idealistiselle estetiikalle. (Sevänen 1991a, 160-161; Sevänen 1991b 296-297.)

\footnotetext{
${ }^{1}$ Tässä viittaan laajasti yhteiskuntatieteiden modernisaatioteorioihin. Yhteiskuntatieteitä, erity isesti sosiologiaa jäsentää ajatus modernismista ja modernisaatiosta. Tieteenalan voidaan suureksi osaksi katsoa perustuvan erilaisille teoreettisille pohdinnoille siitä, millaisia tekijöitä modernisaatio -kehitykseen liittyy ja mihin modernisaatio johtaa. Taiteen ja kulttuurin osalta modernisaation vaikutuksia ovat pohtineet perusteellisimmin ns. Frankfurtin koulukunnan edustajat ja Jürgen Habermas.
} 
Taiteen asemaa modernissa yhteiskunnassa on hahmotettu esimerkiksi käsitteillä taidemaailma, instituutio ja kenttä. Kenttä-käsite on peräisin Pierre Bourdieun (1984) teoriasta, jossa hän tarkastelee modernin yhteiskunnan luokkarakenteen muodostumista. Bourdieun teorian keskeisenä tavoitteena on osoittaa se dynamiikka, jonka myötä kulttuurin tuotteista tulee yhteiskunnallisen luokan osoittajia.

Taidemaailma-käsite liittyy puolestaan institutionaaliseen taideteoriaan, jota ovat kehitelleet George Dickie ja Arthur Danto. Kuitenkin Dickietä pidetään varsinaisesti institutionaalisen taideteorian luojana. ${ }^{2}$ Teoriassaan Dickie pyrkii kuvaamaan sitä päätöksentekoprosessia, joka johtaa tietyn objektin pitämiseen taiteena. Hän etsii yleisiä ominaisuuksia, joita taiteeksi määriteltävälle objektille annetaan. Näitä ovat esimerkiksi arvottavan tarkastelun kohteena oleminen, statuksen ansaitseminen ja originaalisuus (teos on uusi suhteessa traditioon). (Dickie 1981, 83-93) Kuitenkaan Dickie ei kiinnitä huomiota statuksia myöntävän ryhmän sosiaalisiin ominaisuuksiin: jäsenten asemaan, valtaan jne. Dickien lähestymistapa onkin eräällä tapaa filosofinen. Määritellessään rajaa taiteen ja ei-taiteen välille Dickie etsii taiteen olemusta, mutta estetiikan sijaan hän tarkastelee sosiaalisia ja kulttuurisia toimintakäytäntöjä. Teorian ongelmana voi pitää Sepänmaan $(1991,149)$ tavoin sitä, että taiteen ja ei-taiteen välisen rajan määritteleminen on jo siinäkin mielessä kyseenalaista, että taide on instituutiona dynaaminen: sen piirissä syntyy jatkuvasti uutta. Tätä dynaamisuutta Dickie ei teoriassaan tarpeeksi huomioi.

Taidemaailma-käsitettä on käytetty myös konkreettisemmin kuvaamaan taiteen asemaa yhteiskunnassa ja sen toimintaperiaatteita. Tällöin taidemaailma on määritelty historiallis-yhteiskunnalliseksi muodosteeksi, jolla on legitiimi asema suhteessa populaari- ja kansankulttuuriin. Tätä määrittelyä käytän myös tässä artikkelissa, koska se luo mielestäni tarpeeksi joustavan viitekehyksen tarkastelulle. ${ }^{3}$ Lepistön $(1991,24)$ mukaan taidemaailman voidaan nähdä muodostuvan virallisista instituutiosta ja epävirallisista yhteisöistä. Tällöin siihen kuuluvat esimerkiksi taidehallinto, taiteen lainsäädäntö, taidekritiikki, koulutus- ja apurahajärjestelmä ja taiteilijoiden järjestöt ja myös esimerkiksi taiteen tutkimus. Toisaalta Lepistö (mt) tarkastelee taidemaailmaa myös erityisenä sääntö- ja normijärjestelmänä, joka ohjeistaa taiteilijaksi tulemista ja taiteilijana toimimista. Kyseisten kriteerien kautta määritellään esimerkiksi

2 Arthur Danto muotoili ensimmäisenä institutionaalisen teorian artikkelissaan "The Artworld". Dickie on luonnostellut teoriaansa teoksissa "Aesthetics. An Introduction" (1971), "Art and Aesthetics. An Institutional Analysis" (1974) ja "The Art Circle: A Theory of Art"' (1984).

${ }^{3}$ Suomalaisessa taiteentutkimuksessa taidemaailma-käsitettä on perusteellisimmin soveltanut Vappu Lepistö suomalaista kuvataidetta koskevassa tutkimuksessa: 'Kuvataiteilija taidemaailmassa" (1991). 
taiteellinen kompetenssi. Kuitenkin nämä säännöt ja normit ovat usein julkilausumattomia, eikä niitä yleensä tiedosteta tai reflektoida. Ne "opitaan" siinä vaiheessa kun taiteilija sosiaalistuu taidemaailmaan ja hankkii ammatillisen kompetenssin. Tällä lähestymistavalla on yhteyksiä etnometodologiseen tutkimussuuntaukseen (esim. Garfinkel 1967), jonka lähtökohtana on tuoda esille arkielämän - tässä taidemaailman - käytäntöjen taustalla olevat usein itsestään selvät ja annettuina otetut julkilausumattomat säännöt ja normit, jotka ohjaavat toimintaa. ${ }^{4}$

Kun taidemaailmaa on tarkasteltu suhteessa ympäröivään yhteiskuntaan, eivät taiteensosiologit ole välttyneet käyttämästä autonomia-käsitettä. Tämä suhde on tavallisesti määritelty siten, että taiteella on suhteellinen autonomisuus. Kuten edellä on tullut ilmi, käsitys on keskeinen myös useissa modernisaatioteorioissa: taide nähdään historiallisesti muodostuneeksi, omaksi sosiaalisen toiminnan muodoksi, joka on jossain määrin omalakinen suhteessa muihin sosiaalisen toiminnan muotoihin. Suhteellinen autonomisuus on määritelty esimerkiksi siten, että taiteessa on historiasidonnaisten ainesten ohella universaaleja aineksia. Toisaalta taiteen on katsottu muuttuvan eri tahdissa kuin ympäröivä yhteiskunta; taiteesta löytyy aina jälkiä aiemmista tyylisuunnista ja niiden ilmaisukonventioista. Näiden avulla se muokkaa nykyisyydestä saamiansa aineksia. (Sevänen 1991, 296-299).

Myös länsimaisen taidemusiikin tutkimuksessa tutkimuksen lähtökohtana on ollut käsitys musiikin suhteellisesta autonomisuudesta. Musiikki on hahmotettu yhteiskunnallis-historialliseksi ilmiöksi, mutta samalla musiikin autonomisuutta on korostettu erityisellä tavalla. Tämä on näkynyt mm. siinä, että taidemusiikin tutkimus ei ole läheskään aina kontekstualisoinut tutkimuskohteitaan. Vaikka siis musiikin suhteellinen autonomisuus on ollut tutkimuksen lähtökohtana, tutkimuskäytännöissä musiikin suhde yhteiskuntaan on koettu problemaattisena. (Heiniö 1992, 12-15.) Tästä näyttääkin löytyvän painotusero

\footnotetext{
${ }^{4}$ Instituution käsitettä musiikin kannalta on pohtinut Heiniö (1990) varsin perustellusti. Hänen mukaansa instituution konstitutiivisena voidaan pitää tehtävää, aatetta, materiaalista apparaattia ja henkilöstöä. Oma mielenkiintoni on kuitenkin taidemaailman '"kirjoittamattomien sääntöjen" ja konventioiden etsimisessä (omassa tutkimusaiheessani tämä kiteytyy taiteen ja populaarin rajan määrittelyn dynamiikkaan), jolloin instituution käsite sinällään on liian suppea tutkimuslähtökohdaksi.

Esimerkkinä "'kirjoittamattomista säännöistä" ovat Lepistön (1991) mukaan länsimaisessa taiteessa eri aikoina vallinneet myytit taiteilijasta nerona ja boheemina. Tosin myös Heiniö viittaa "'kirjoittamattomiin sääntöihin": "Musiikki-instituutiotakin voidaan tarkastella sarjana uskomuksia, jotka ovat yhteisiä tietyn, musiikkiin liittyvän päämäärän hyväksi toimiville ihmisille. Jokaisella musiikki-instituutiolla on sekä eksplisiittisiä sääntöjä - siis sääntöjä sanan arkimerkityksessä - että implisiittisiä sääntöjä, jotka piilevät uskomusten järjestelmässä tämän normatiivisena aspektina" (Heiniö 1990, 16-17).
} 
suhteessa edellä referoimaani sosiologiseen teoriaperinteeseen. Suhteellinen autonomisuus ei näytä olevan niissä yhtä selkeästi ennakolta asetettu lähtökohta vaan ominaisuus, joka täytyy rekonstruoida - ja myös problematisoida tutkimuksessa kerta toisensa jälkeen uudelleen. Tällöin lähtökohtana on se, että taide on aina luonteeltaan historiallisesti ja kulttuurisesti ehdollista (Lepistö 1991, 23-24).

Kysymys taidemaailman ja muiden sosiaalisten järjestelmien välisen yhteyden luonteesta on sinänsä laajempi kysymys, jonka käsittely ei ole mahdollista tässä yhteydessä. Suhdetta on pohdittu erityisesti dialektisessa ja marxilaisvaikutteisessa tutkimuksessa. Jürgen Habermasin näkökulma poikkeaa huomattavasti yleensä pessimistisistä kriittisistä modernisaatioteorioista. Hän näkee modernin vastakkainasetteluna "systeemin" ja "elämismaailmojen" välillä. Systeemi rakentuu päämäärärationaalisuudelle ja elämismaailma on yksilön subjektiivinen elämänpiiri. Eriytyneillä instituutioilla, kuten taideinstituutiolla, on tässä välittävä rooli. Niiden omalakisuus tarjoaa mahdollisuuksia erilaisten maailmankuvien rakentamiselle ja estää näin "elämismaailmojen kolonialisoitumisen". (Esim. Kotkavirta 1991, 212-219.)

Peter Bürgerin (1984) tavoin taideinstituution ja yhteiskunnan suhdetta voidaan tarkastella historiallisesti. Keskiajalla taide oli vielä kiinteästi yhteydessä muihin järjestelmiin, esimerkiksi uskontoon, mutta modernissa yhteiskunnassa taiteen käytännön tehtävät vähenivät ja taiteen funktio tuli vaikeammaksi hahmottaa. Kiinnostava tämän artikkelin kannalta on Peter Bürgerin näkemys avantgardeliikkeestä porvarillisen taideinstituution itsekritiikkinä. Tähän palaan lyhyesti artikkelin lopussa.

Suomalaisen taidejärjestelmän historiallista tarkastelua edustaa Erkki Seväsen (1994) tutkimus kirjallisuuden tuotannon ja välityksen yhteiskunnallisesta säätelystä Suomessa vuosina 1918-1939. Tutkimuksessaan Sevänen tarkastelee empiiris-historiallisesti suomalaista kirjallisuusjärjestelmää ja niitä institutionaalisia puitteita, joissa kirjallisuuden välitys ja tuotanto tapahtuivat ja jotka osaltaan sääntelivät kirjallisen tarjonnan luonnetta ja sisältöä. Tarkastelu tehdään sekä kirjallisuusjärjestelmän sisällä että suhteessa muihin järjestelmiin ja muuhun yhteiskuntaan. Seväsen tutkimus tuo esille keskeisesti niitä historiallisia taustatekijöitä, jotka ovat muovanneet suomalaista taidejärjestelmää.

\section{Taiteilija, traditio ja tyyli}

Sosiologista tutkimustapaa voidaan kuitenkin kritisoida siitä, että se keskittyy enemmänkin siihen mikä tekee taiteilijan kuin mitä taiteilija tekee, eli se ei ole kiinnostunut taiteen sisällöstä, vaan taiteen ja taiteilijakuvan tuottamisesta yhteiskunnassa. Tradition sisäisen kehityksen tarkastelun liittäminen osaksi taiteen sosiologista tutkimusta laajentaa tutkimusnäkökulmaa, mutta tuo samalla myös ongelmia. Konkreettisin lienee tutkimusongelman vaikea hallit- 
tavuus. Kuitenkin tradition sisäisen materiaalis-esteettisen historian huomioiminen on mielestäni tärkeää myös sosiologisesti painottuvassa tutkimuksessa. Esimerkiksi taidemusiikissa on tällöin kysymys muuttuvista teknillis-tyylillisistä keinovaroista ja niitä koskevista arvioinneista. Taidemusiikissa tradition sisäisen historian merkitys onkin erityisen suuri, koska musiikki ei sinänsä viittaa suoraan mihinkään ulkopuolella olevaan. Mutta kuitenkaan musiikkia ei voi pitää suljettuna systeeminä. (Shepherd 1991, 13.) Sinänsä kuvatunlainen lähestymistapa on ominaista länsimaisen taidemusiikin tutkimukselle (ks. esim. Heiniö 1992). Kuitenkin suhtaudun tradition sisäiseen historiaan taidemaailman ominaisuutena, erityisenä diskurssina. Tällöin sille voi asettaa kysymyksen: mitä se, että traditioon kuuluvista ilmiöistä puhutaan ja niitä arvotetaan tietyllä tavalla, kertoo tästä traditiosta

"Mitä taiteilija tekee?" -kysymys johtaa ongelmaan, mikä osuus tarkastelussa asetetaan taiteilijan persoonallisille ominaisuuksille, luovalle subjektille. Länsimainen käsitys taiteilijasta sisältää paljon myyttisiä aineksia, joiden juuret pohjautuvat renessanssiajan yksilölliseen luojahahmoon ja individualistiseen ihmiskuvaan. Myyttiseen taiteilijakuvaan kuuluu keskeisesti käsitys taiteilijasta modernin rationaalisen yhteiskunnan kääntöpuolena, irrationaalisuuden ja anarkistisuuden osoittajana. (Esim. Lepistö 1991, 15-16.) Myyttisen taiteilijakuvan olemassaoloa ilmentää taiteilijaelämäkertojen suosiminen ja ylipäätään psykologisoiva ote usein myös taiteentutkimuksessa. Taiteilijakuvaan liittyvät myyttiset ainekset ovat varmasti myös osaltaan vahvistaneet käsitystä taiteen autonomisuudesta. Musiikin alueella tämä on näkynyt erityisesti populaarissa musiikkikirjoittelussa, jota voi sanoa leimaavan vielä nykyäänkin "hegeliläisen sankarihistorian" henki.

Käsitys individualistisesta subjektista johtaa usein tarkastelutapaan, jonka mukaan tyyli on ainutkertaista. Länsimaisessa taiteessa yksilöllinen tyyli on ollut yksi luovuuden keskeinen kriteeri. (Lepistö 1991, 153-154.) Toisaalta yksilön ainutkertaisuutta korostava lähestymistapa on liittynyt myös tyylintutkimukseen, esimerkiksi Barthes (1987) tulkitsee tyylin taiteilijan refleksinomaisena ja tiedostamattomana "käsialana". Tyyli on Barthesille henkilökohtainen prosessi, eikä hän näe siinä mitään yhteiskunnallista. Kuitenkin yleensä esimerkiksi musiikintutkimuksessa, niin musiikkitieteessä kuin etnomusikologiassakin, tyyli-käsitteen avulla on pyritty luomaan sopivia tutkimuskategorioita. Taiteen alueella kiinnostava seikka piilee kuitenkin siinä, että usein tyylintutkimuksessa tyyli on - ainakin implisiittisesti -nähty lineaarisena ja johdonmukaisena kokonaisuutena. Jos taiteilija on tehnyt useita tyylillisiä kokeiluja, on häntä voitu syyttää "kyvyttömyydestä löytää ominta tyyliään" (esim. Lepistö 1991, 153-156). Näkökulman voidaan katsoa liittyvän keskeisesti moderniin taidekäsitykseen.

Postmoderni ideologia on kyseenalaistanut ajatuksen lineaarisesta ja johdonmukaisesta kehityksestä "suurena kertomuksena". Kyseenalaistaminen on tuonut Lepistön $(1991,163)$ mukaan mahdollisuuden lähestyä tyyliä her- 
meneuttisena ja dialektisena prosessina. Taiteen tekeminen voidaan tällöin nähdä kysymyksen ja vastausten logiikkana, "implisiittisten ja eksplisiittisten vastausten kehittämisenä taidemaailmassa esiintyville yleisille ja taiteilijan yksilöllisesti muotoilemille kysymyksille" (Lepistö 1991, 162). Kysymykset voivat olla luonteeltaan esteettisiä, filosofisia ja psykologisia, mutta yhtä hyvin yhteiskunnallisia tai poliittisia. Lisäksi keskeistä on, että taiteilijan työ on sosiaalista toimintaa: taidemaailman konventiot ja suuntaukset ovat taiteilijan tietoisuudessa läsnä tavalla tai toisella.

Seuraavassa tarkastelen suomalaista 1960-luvun alun taidemusiikkia suhteellisen autonomisuuden näkökulmasta. Vertaan suomalaisen taidejärjestelmän yleistä historiallista kehitystä taidemusiikin ilmiöihin, erityisesti avantgarde-liikkeeseen. Toisaalla on tradition oma sisäinen kehitys, musiikin historia, jonka myös huomioin sinänsä. Kolmanneksi huomion kohteena ovat ne toimintakäytännöt, jotka yhdistävät kahta edellistä. Käytännössä tämä tarkoittaa keskeisten teosten, niiden taustan, kritiikin ja taidemusiikin piirissä käydyn yleisen keskustelun tarkastelua. Sen tehtävänä on hahmottaa taidemusiikin kentän keskeisiä piirteitä tässä historian vaiheessa. Sinänsä tällainen kysymyksenasettelu on laajan tutkimuksen aihe, mutta tässä tarkastelen ongelmaa esimerkinomaisesti kahden säveltäjän tuotannon valossa. ${ }^{5}$

\section{Suomalainen taidejärjestelmä ja sen erityispiirteet}

Suomessa taidealojen eriytyminen on Keski-Eurooppaan verrattuna tapahtunut varsin myöhään, vuosisadan vaihteesta alkaen. Esimerkiksi taidemusiikin piirissä organisoitumisen voidaan katsoa alkaneen 1880-luvulla, jolloin perustettiin Helsingin Musiikkiopisto ja Helsingin Orkesteriyhdistys, mikä merkitsi koulutus-ja orkesteritoiminnan saattamista vakinaiselle tasolle.

Itsenäistymisen jälkeen taiteesta muodostui yksi kansallista identiteettiä pönkittävä tekijä, koska taiteella historiankirjoitusta paremmin pystyttiin luomaan kunniakasta menneisyyttä nuorelle valtiolle. Toisaalta nuoren ja pienen

\footnotetext{
${ }^{5}$ Ajankohdan rekonstruoimisessa keskeisinä lähteinä ovat olleet säveltäjien tuotannot, jotka olen pyrkinyt kokoamaan mahdollisimman systemaattisesti, sen lisäksi olen aiemmin (Rautiainen 1992) käynyt läpi ajankohtana käytyä lehtikeskustelua. Lisäksi olen pyrkinyt käymään läpi mahdollisimman paljon erilaisia ajankohtana syntyneitä dokumentteja: elokuvia, TV-ohjelmia ja radio-ohjelmia ja myös esimerkiksi yleistä taiteen piirissä käytyä keskustelua.

Tämän lisäksi olen haastatellut säveltäjiä ja muita ajankohtana aktiivisesti toimineita henkilöitä. Haastatteluaineiston käyttö voi herättää kritiikkiä, jos lähtökohdaksi asetetaan pyrkimys käyttää haastatteluaineistoa "totuuden" selvittämiseen. Tässä artikkelissa olen käyttänyt haastatteluaineistoja niissä yhteyksissä, joissa ne ovat asiasisällöllisesti olleet yhteneviä oman tulkintani kanssa.
} 
valtion poliittiset jännitteet heijastuivat taide-elämään. Erityisesti kansalaissodan jälkeen yhteiskuntajärjestyksen lujittaminen ja integraation palauttaminen olivat keskeisiä tehtäviä. Siten nationalismista ja patriotismista muodostui porvariston arvomaailman perusta. (Sevänen 1994, 98.) Keskeistä suomalaiselle taide-elämälle onkin ollut se, että suhteellisesta itsenäisyydestään huolimatta sitä on pyritty sitomaan kansalliseen arvojärjestelmään: kirkko ja valtio pyrkivät aina 1950-luvulle asti ulottamaan poliittis-ideologista ja uskonnollis-moraalista valvontaa taide-elämää kohtaan. Valvonta on tullut näkyviin esimerkiksi traditionalistisen muotokielen suosimisena, sillä esimerkiksi kirjallisuuden piirissä modernismi koettiin ensimmäisen tasavallan aikana olevan ristiriidassa vallinneiden kansallisten perusarvojen kanssa. (Sevänen 1994, 390.) Uskonnollis-moraalisen valvonnan taustalla on puolestaan se, että koko taidejärjestelmämme synty on kiinteässä yhteydessä kansanvalistukseen. Kansalle soveliaan ja ei-soveliaan rajan määrittely on tullut monasti esille musiikin alueella siten, että tietty musiikillinen ilmiö on tuomittu moraalittomaksi. Näin suhtautui esimerkiksi jazziin osa säveltäjistä 1920-luvulla ja monet nuorten harrastusorganisaatiot vielä 1950-luvullakin. (Tuomikoski-Leskelä 1977, 263-272, Jalkanen 1989, 334-338, Kurkela 1986. $)^{6}$

Eurooppalainen modernismi alkoi vaikuttaa suomalaiseen taide-elämään tämän vuosisadan alussa. Modernismin virtaukset näkyivät läpi taiteen kentän, erityisesti kuitenkin suomenruotsalaisen lyriikan piirissä. Vaikka taiteen sisällä oli liikkumatilaa, tulivat ainekset ilmaisukielen muuttamiseen kuitenkin lähinnä vain ranskalaisesta symbolismista ja omasta perinteestä. Vasta toisen maailmansodan jälkeen suomalainen kulttuurielämä näytti olevan valmis kokonaisuudessaan kohtaamaan ne yleiseurooppalaiset moraaliset, sosiaaliset ja esteettiset muutokset, jotka muualla olivat tehneet tuloaan jo viime vuosisadan lopulta lähtien. Suhteellisen yhtenäiseen esteettiseen ja aatteelliseen ilmastoon, jota sodanjälkeinen jälleenrakennuskausi osaltaan vahvisti, alkoi muodostua nyt ajatuksia estetiikan ja taiteen ilmaisukeinojen moniarvoisuudesta. Taustalla oli nuoren suomalaisen älymystön jakama näkemys siitä, että suomalainen taide-elämä oli jäänyt jälkeen kansainvälisestä kehityksestä ja umpioitunut. Suomi tuli jälleenrakentaa henkisesti ja aineellisesti sekä kulttuurielämä uudistaa ja tähän eivät soveltuneet enää sotaa edeltäneet henkiset arvot. Ne koettiin vanhentuneiksi ja ne joutuivat parodian kohteeksi. (Kunnas 1981, 8-10; 195197.)

6 On kuitenkin huomattava, että nämä ovat suomalaista taideinstituutiota koskevia yleistyksiä ja sinänsä vain suuntaa antavia. Millaista valvonta on ollut kunkin taiteenalan kohdalla olisi tutkittava erikseen. Tämäntyyppisestä tutkimuksesta on esimerkkinä Seväsen (1994) työ. Suomalaisen taidemusiikin tutkimuksessa tämäntyylistä kysymyksenasettelua ei tiettävästi ole ollut. 


\section{Suomalainen taidemusiikki 1950-luvulla: modernismista avant- gardismiin}

Taidemusiikin piirissä selkeämpi irtautuminen kansallisromantiikasta ajoittuu myös 1950-luvulle, jolloin dodekafonia ja sarjallisuus alkavat laajemmin tulla suomalaisten säveltäjien tietoisuuteen. Mutta kehityksellä on erityispiirteensä: dodekafonia omaksutaan pikemminkin metodina kuin tyylinä ja sarjallisuus tulee esille vain harvoissa suomalaisissa teoksissa. (Heiniö 1991, 224-225.) Jos musiikillisissa vaikutteissa liikuttiin nyt uusilla alueilla, nuoret kriitikot ja säveltäjät halusivat myös yleisellä tasolla herättää keskustelua suomalaisen taidemusiikin tilasta ja musiikkikasvatuksesta. Konkreettinen esimerkki tästä oli vuonna 1955 useissa lehdissä julkaistu julkilausuma: "Musiikin hälytys - hälytys musiikkikulttuurimme kestämättömän tilanteen johdosta". 7 Ankarin kritiikki ja uudistusvaatimukset kanavoituivat myöhemmin vuonna 1957 perustettuun Suomen Musiikkinuoriso -yhdistyksen kautta. Siitä muodostui 1960-luvun alussa nuoren muusikkopolven löyhä yhteenliittymä, joka otti keskeiseksi toiminta-alueekseen uuden musiikin esilletuomisen. Tuolloin yhdistyksen puheenjohtajaksi tuli Erkki Salmenhaara ja toimintaan liittyi mukaan joukko nuoria säveltäjiä ja kriitikoita mm. Seppo Heikinheimo, Kaj Chydenius, Kari Rydman, Ilkka Oramo, Otto Donner, Ilpo Saunio, Erkki Kureniemi ja Raimo Hankiranta. Ryhmäläiset näkivät suomalaisen musiikkielämän vanhoillisena ja siinä näkyvät modernistiset piirteet pintapuolisina. Keskeisiä kritiikin aiheita olivat modernismin huono tuntemus ja haluttomuus etsiä uusia ilmaisumuotoja. Kaikkein poleemisimmin nämä ajatukset toi esille Kari Rydman, joka syytti suomalaista modernismia sen jäämisestä "Schönberg ja Bartok-vaiheeseen" (Rydman 1960). Tilalle nuori polvi alkoi vaatia "avantgardismia". Impulsseja tähän haettiin Darmstadtin kesäkursseilta, jossa suomalaiset säveltäjät ja kriitikot olivat vieraillet jo 1950-luvun puolivälistä lähtien. Huomio kiinnittyi erityisesti Stockhauseniin, Bouleziin ja Nonoon, jotka keräsivät huomiota myös laajemmin kuin pelkästään musiikkinuorisolaisten keskuudessa. Suomalaisilla oli myös suoria kontakteja kyseisiin säveltäjiin, $\mathrm{mm}$. Stockhausen vieraili vuosikymmenen vaihteessa useaan otteeseen Suomessa. (Ks. myös Heiniö 1986, 42-58.)

Mutta 1960-luvun alussa nimenomaan Suomen Musiikkinuorison piirissä nuoret säveltäjät päätyivät ajatteluun, jota Kaj Chydenius (haastattelu 1992) on luonnehtinut "epäkunnioittavaksi modernismiksi". Taustalla oli Keski-Euroopan modernismin kehitys, jossa ankara sarjallisuus johti paradoksaalisesti täysin vastakkaiseen ilmiöön: aleatoriikkaan. Tämä huomioitiin myös suoma-

7 Julkaistu mm. Ylioppilaslehdessä 15.4.1955. Hälytyksen sisällöstä ks. Rautiainen $1992,16-25$. 
laisten keskuudessa. Kaj Chydeniuksen matkaraportti Darmstadtista vuodelta 1961 oli otsikoitu "Sarjallisen musiikin aika on ohi" (Chydenius 1961). Artikkelissa Chydenius referoi Ligetin keskeisiä ajatuksia, joiden mukaan avantgardismi oli "ristiaallokossa": läpisarjallinen ja aleatorinen musiikki olivat 1950luvun kehityksen ääripäät. Kun nämä tiet oli nyt kulutettu loppuun, oli säveltäjien itse alettava etsiä musiikin uutta suuntaa, ja tämä oli myös Chydeniuksen viesti. Suomen Musiikkinuorison piirissä uusiin ajatuksiin tartuttiin varsin pian: muutamat nuoret säveltäjät lähtivät omissa teoksissaan etsimään musiikin uutta suuntaa. Radikaalimpaan avantgardeen, minkä leiman tämä musiikki varsin pian sai, musiikkinuorisolaisista suuntautuivat nyt pääasiassa Otto Donner, Erkki Salmenhaara, Kari Rydman sekä kriitikoista Kaj Chydenius ja Ilpo Saunio (ks. myös Heiniö 1986, 54-55).

\section{Avantgarden lähtökohdat}

Nuoren polven kiinnostus ulottui aluksi lähes kaikkiin 1950-luvun Keski-Euroopan modernismin keinovaroihin ulottuen sointiväristä uudenlaiseen musiikillisen materiaalin käyttöön ja uusien muotoratkaisujen etsimiseen asti. Yksi keskeisistä innoittajista Musiikkinuorison keskuudessa oli John Cage. Vaikka siis Chydenius Ligetiä lainaten totesi aleatoriikan jäävän historiaan, ei tämä näyttänyt pitävän paikkaansa Suomen Musiikkinuorison piirissä; aleatoriikasta muodostui varsin pian keskeinen lähtökohta radikaalin avantgarden puolesta puhuville säveltäjille. Toisaalta esimerkiksi Cage herätti varsin ristiriitaisia tunteita, mutta myöhemmin muutamat säveltäjistä ovat pitäneet häntä eräänlaisena "guruna" senhetkisessä tilanteessa. (Chydenius, haastattelu 1992; Donner, haastattelu 1994). Aleatoriikan lisäksi keskeiseksi kiinnostuksen kohteeksi nuorille suomalaisille säveltäjille nousivat ns. Puolan koulukunnan sointivärimusiikki ja Ligetin kenttätekniikka. Kiinnostus kääntyi myös laajemmin elektronimusiikkiin.

Keskeiseksi avainkäsitteeksi näytti muodostuvan nyt musiikillisen ilmaisun laajentaminen. Perinteisiä käsityksiä siitä, mitä musiikki voi ja voisi olla, haluttiin nyt laajentaa kaikkiin suuntiin. Vaikka suhteet Eurooppaan olivat tiiviit, ei nuorten suomalaisten säveltäjien lähtökohtana näyttänyt olevan niinkään tietyn koulukunnan seuraaminen, vaan uusien vaihtoehtojen kokeileminen ja joissain tapauksissa myös kehitteleminen. 1960-luvun alkuvuosina Suomen Muusikkonuoriso esitteli musiikin avantgardea konserteissa, joita kriitikot alkoivat nimittää 'lastenkamarikonserteiksi". 1960-luvun alun kiihkeän etsinnän vuodet johtivat kuitenkin tilanteeseen, jossa niin taidemusiikin kuin taiteen estetiikka yleensä joutui arvioinnin kohteeksi. Seuraavassa tarkastelen tätä kehitystä Otto Donnerin ja Kari Rydmanin tuotannon valossa. (Ks. myös Heiniö 1988, 25-28, Wallner 1968, 251-258.) 


\section{Henrik Otto Donner}

Otto Donner aloitti sävellysopintonsa Sibelius-Akatemiassa vuonna 1958 opettajinaan mm. Nils-Erik Fougstedt ja myöhemmin Joonas Kokkonen. Tätä ennen hän oli kuitenkin jo toiminut jonkin aikaa jazz-muusikkona. Kiinnostus uutta musiikkia kohtaan oli vielä 1950-luvun lopussa vähäistä Sibelius-Akatemiassa: dodekafonian opetus jäi periaatteiden esittelyn tasolle ja sarjallisuus sivuutettiin kokonaan. Niinpä tieto oli haettava niin Ernst Krenekin oppikirjasta (Zwölfton Kontrapunkt Studien, 1952) kuin ulkomaisten kontaktien avulla (Donner, haastattelu 1994; ks. myös Heiniö 1986, 13). Donnerin mielenkiinnon suunta, dodekafonia ja toisaalta aleatoriikka, on nähtävissä ensimmäisissä, vuosina 1961 ja 1962 syntyneissä sävellyksissä: Tre stycken för piano, Tre stycken för flöjt och piano ja Tre studier för kör. Mainituista ensimmäinen hyödyntää vielä dodekafoniaa, mutta seuraavassa teoksessa, Tre stycken för flöjt och piano, Donnerin tyytymättömyys perinteisiin ilmaisumuotoihin alkaa tulla esille. 1950-luvun modernismin keskeiset innovaatiot tulevat nyt kokeiltavaksi, tässä teoksessa erityisesti uuden musiikin notaatio. Teoksen keskeinen idea perustuu vastakohtaisuudelle: ääriosat perustuvat perinteiselle ja keskiosa graafiselle notaatiolle. Keskiosa muodostuu seitsemästä erillisestä graafiseen notaatioon perustuvasta ryhmästä ja siinä tarkoituksena on improvisoida teoksen ensimmäisen osan 12-sävelrivin karakteristisilla intervalleilla. Esittäjä voi vapaasti valita ensimmäisen ryhmän, mutta sen jälkeen on edettävä järjestyksessä: alkuun voidaan palata vasta sitten, kun kaikki muut ryhmät on soitettu. Kysymyksessä on siis ns. monimerkityksellinen muoto (ks. esim Maegaard 1984, 86-87.) Teosta esitellyt Ilpo Saunio (1962) näki sen keskeisenä tarkoituksena olevan yksiselitteisten symbolien etsimisen uuden notaatiosysteemin kehittämiseksi. Vastaavia kokeiluja löytyy samalta ajalta Erkki Salmenhaaralta ja Kari Rydmanilta.

Tre Studier för blandad kör Gunnar Björlingin runoon sekakuorolle, puhekuorolle ja sopraanosolistille on nimensä mukaisesti tutkielma ihmisäänen käyttömahdollisuuksista. Myös tämä teos voidaan tulkita Darmstadt-vaikutteiden työstämiseksi: tekstin muokkaaminen musiikillisiksi elementeiksi siten, että vokaali- ja konsonanttiväreistä tulee musiikillisia aineksia, oli keskeisiä 1950-luvun modernismin kokeiluja. Ensimmäisessä osassa Donner käyttää puhekuoroa, jolle hän on kuitenkin merkinnyt summittaiset sävelkorkeudet. Teksti pilkotaan siinä tavuiksi ja äänteiksi ja yhdistetään soinnillisiin keinovaroihin kuten glissandoon. Kahdessa muussa osassa Donner jatkaa, tosin perinteisellä nuottitekstuurilla, runon pilkkomista yksittäisiin äänteisiin.

Keskeiseksi innovaatioiden lähteeksi Donner on myöhemmin (Donner, haastattelu 1994) luonnehtinut Darmstadtin kesäkursseja, jossa hän vieraili ensimmäisen kerran vuonna 1962. Tuolloin kurssilla kiinnostuksen kohteina olivat Stockhausenin parametreihin perustuva sävellystekniikka, aleatoriikka, graafinen notaatio ja musiikin tila- ja muoto-ongelmat. Luennoijina oli avant- 
garden eturivi: Ligeti, Stockhausen, Boulez ja Nono. Erityisesti Bouleziin on viitattu Cantata Profanan (1962) (sopraanolle, tenorille, baritonille, kamariyhtyeelle ja ääninauhalle) yhteydessä (Heiniö 1988, 35). Teoksessa yhdistyvät monet 1950-luvun keinovarat: tekstuuri ulottuu kompleksisesta sointikudoksesta hitaasti muuttuvaan sointikenttään. Sointivärien etsiminen jatkuu myös vokaaliosuuksissa, joissa ilmaisuskaala ulottuu puhelauluun ja tekstin lausumiseen saakka. Teksti koostuu mm. Hans Magnus Enzensbergerin ja Gregory Corson runoista. Teoksen viimeisessä osassa pianon, lyömäsoitinten ja vibrafonin osuus johdetaan vielä samanaikaisesti kaikunauhalle.

Donnerin mielenkiinto oli Cantata profanan myötä kääntynyt musiikin muotoajattelun ongelmiin ja erityisesti tilan ja musiikin suhteeseen. Eräänlainen kannanotto tähän oli teos Ideogramme I (1962) kahdelletoista radiolle, huilulle, klarinetille, pasuunalle ja lyömäsoittimille. Kolmiosainen ja noin kuusi minuuttia kestävä teos perustuu sekuntinotaatioon ja siinä eri puolelle salia sijoitettujen radioiden volyymia ja äänenväriä muuttamalla luodaan sointikenttiä. Tämän päälle puhaltimet ja lyömäsoittimet soittavat oman osuutensa. Soittimien tekstuuri on osaksi sarjallista. Donnerin alkuperäinen suunnitelma oli, että yleisö liikkuisi vapaasti ympäri konserttitilaa, mikä olisi kokeilu äänen ja tilan yhteensovittamisen suhteen. Tämä suunnitelma ei kuitenkaan toteutunut. Myöhemmin hän näki teoksen keskeisenä tarkoituksena olevan perinteisen konserttikäytännön rikkomisen. (Donner 1963; Donner, haastattelu 1994). Konsertti-instituution kritiikistä muodostuikin varsin pian yksi Donnerin teosten keskeisistä teemoista, mutta Ideogramme I näyttää korostetummin viittaavan toiseen, Donneria myöhemminkin kiinnostaneeseen seikkaan: musiikin ja hälyn välisen rajan esilletuomiseen. Hälyn ja musiikin yhdistäminen oli tyypillistä jo vuosisadan alun futuristeille, mutta 1960-luvulla yhdistämiselle haettiin perusteluja informaatioteoriasta. Informaatioteorian kautta kiinnostuttiin erityisesti äänen ja hälyn välisestä rajasta. Informaatioteoria kuvaa sanoman informaatioarvoa: mitä suurempi on sanoman ennakoitavuus, sitä pienempi informaatioarvo ja päinvastoin. Keskeinen lähtökohta Ideogramme I: ssä näyttääkin olevan, miten instrumenttien osuus suhteutuu radioiden kohinaan ja toisaalta asemien ääni-informaatioon: miten ääni muuttuu musiikista hälyksi ja häly musiikiksi. (Maegaard 1984, 73-77; Donner, haastattelu 1994.)

Donner kiinnostui kuitenkin varsin pian erilaisesta estetiikasta kuin mitä Darmstadtin koulukunnan ideat niin aletoriikassa ja elektronimusiikissa edustivat. Vaikutteet tulivat nyt Yhdysvalloista Ken Deweyn ja Terry Rileyn kautta, jotka hän tapasi Zagrebin Biennalessa vuonna 1963. Tälle estetiikalle, joka sittemmin johti happeningiin, oli ominaista poikkitaiteellisuus, yhteydet teatteriin, tanssiin ja myös jazziin. Donner koki suuntauksen perusajatukset kiinnostavampina kuin esimerkiksi Darmstadtin piirissä vaikuttaneen Fluxus-liikkeen (Donner, haastattelu 1994). Liikkeen ehkä tunnetuimman edustajan Nam June Paikin esiintymiseen kuului usein destruktiivisia piirteitä. Hän tuli tunnetuksi 
mm. siitä, että soitettuaan ensin flyygelillä Chopinia hän särki instrumentin esityksen päätteeksi.

Myös Donnerin omat teokset alkoivat varsin pian saada uudenlaista, poikkitaiteellista leimaa. ${ }^{8}$ Tämä näkyy Ideogramme II:ssa (1963), jossa ilmenee myös selkeästi pyrkimys pois perinteisestä konserttikäytännöstä. Teos esitettiin "Suomi rakentaa" -näyttelyn yhteydessä Helsingin Taidehallissa. 20-henkinen orkesteri oli sijoitettu ympäri Taidehallin saleja, ja teoksen kulkua ohjattiin kellojen ja saleihin johdetun ääninauhan avulla. Yleisöllä oli mahdollisuus liikkua vapaasti eri saleissa. Partituurin mukaan musiikki kulkee teoksen alussa ja lopussa soittajalta toiselle ympyrän muodossa siten, että kukin soitin alkaa soittamaan tiettyä säveltä vuoronperään. Tämä vaihtuu jaksoon, jossa kullakin soittimella käydään läpi eri soittotapoja ohjeiden ulottuessa aina käsien taputtamiseen ja jalalla polkemiseen asti. Tämän jälkeen ohjeeksi tulee soittaa jotakin kyseisen instrumentin tunnettua konserttoa tai sonaattia, kun taas piano, sopraanosaksofoni ja rummut soittavat jazz-sooloa. Kolmannessa osassa soitto-ohje on "ad libitum" ja soittajien tehtäväksi tulee laulaa eri vokaaleja, kunnes teos päättyy kuten se alkoikin: yhtenäisen sointikentän hajoamisena siten, että soittimet jäävät yksitellen pois. (Ks. myös Heiniö 1988, 36.)

Donnerin pyrkimykset kaataa musiikillisia raja-aitoja liittyvät olennaisesti hänen jazz-taustaansa. 1950-luvun lopusta lähtien käytännön muusikon työ oli vienyt hänet Lilla-Teaternin produktioihin, mm. O-Pop Kabareehen, sekä radioon ja televisioon. Jazzin tyylisuunnista Donnerin tausta on 1950-luvun bebopissa, erityisesti John Coltranen ja Miles Davisin musiikissa. Toisaalta 1960-luvun alussa Gunther Schullerin pyrkimykset yhdistää länsimaista taidemusiikkia ja jazzia kiinnostivat Donneria. Yksi keskeinen tavoite hänellä näyttääkin olevan improvisaation tuominen taidemusiikkiin. Donner yhdistää taidemusiikkia ja jazzia välillä hyvinkin suoraviivaisesti, kuten teoksessa Kinetique (1964). Teos on kirjoitettu pienelle orkesterille ja jazz-yhtyeelle. Kappale alkaa sointikentän rakentamisella, jota seuraa Kinetique-lyhytelokuvasta lainattu "blues-teema" (nuottiesimerkki 1) trumpettisooloineen. Tämän jälkeen ohjeeksi annetaan soittaa jotakin duuriasteikkoa niin nopeasti kuin mahdollista, mikä partituurin mukaan päättyy "ryminään". Muita keinovaroja teoksessa ovat eri instrumenteilla soitetut soolot orkesteritekstuurin alle ja esimerkiksi puhaltajilla läppien ja venttiilien helistely.

Poikkitaiteelliselle näkökulmalle Donner löysi vastakaikua myös Vivica Bandlerin johtamasta Lilla Teaternista sekä Helsingin Ylioppilasteatterista. Vivica Bandler toi Lilla Teaternin kautta Suomeen teatterin avantgardea, absur-

\footnotetext{
${ }^{8}$ Ilmeisesti poikkitaiteellista suuntautumista oli vallalla myös laajemmin Euroopassa ja myös Darmstadtin koulukunnan edustajilla, kuten Stockhausenilla. Siten näiden ajatusten syntymisen paikallistaminen, ajoittaminen ja liikkuminen on oman tutkimuksen aihe.
} 
dia teatteria. Vastaavia kokeilevia näyttämöproduktioita Ylioppilasteatterissa olivat Jaakko Pakkasvirran Moraliteetti kuolemasta kasalle näyttelijöitä (1963) ja Markku Lahtelan Kevätsadetta (1964). Donner oli näissä produktioissa mukana niin ideoijana, säveltäjänä kuin esittäjänäkin. Samoihin aikoihin Donnerin yhteistyökumppaniksi tuli myös ohjaaja Eino Ruutsalo, jonka useisiin 1960-luvun alun kokeileviin elokuviin Donner teki musiikin. Elokuvien Don Quiote (1961) ja Kineettisiä kuvia (1962) musiikki on jazzia, josta on kuultavissa 1950-luvun bebop-vaikutteet. Ominaista Donnerin jazz-sävellyksille on jo tässä vaiheessa 12-sävelrivin soveltaminen. (Ks. nuottiesimerkki 1.) Kineettisiä kuvia on hyvä esimerkki tuona aikana kuvataiteessa liikkuneista avantgardistisista suuntauksista. Elokuva rakentuu filmimateriaalille, joka on raaputettu, syövytetty, reijitetty ja maalattu. Tätä materiaalia liikutellaan erisuuntaisesti ja erilaisilla nopeuksilla, jolloin syntyy uudenlaista kuvallista ja ilmauksellista liikettä. Toisenlainen sovellus on niin ikään Ruutsalon kanssa yhteistyönä syntynyt Kotka (1962), jossa tanssija Riitta Vainio esittää tuohon aikaan Suomessa varsin tuntematonta modernia tanssia kotkan hahmossa. Donnerin mielenkiinnon kohteena on tässä liikkeen ja musiikin yhdistäminen. Musiikki perustuu arkaaisen vaikutelman antavaan 5/4-poljentoon, jossa tanssijan liikkeitä korostetaan lyömäsoittimilla.

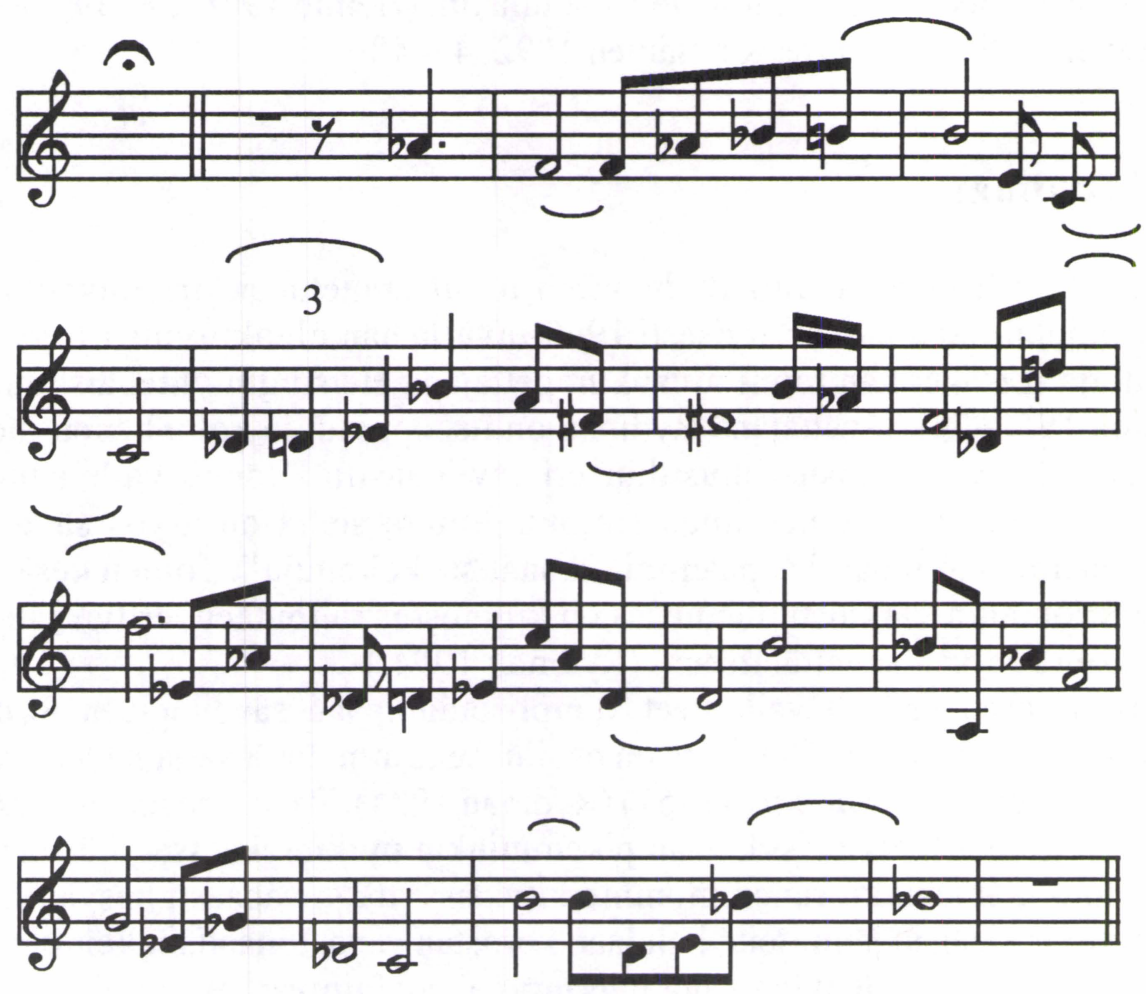

Nuottiesimerkki 1. Otto Donner: Kinetique (1964). 
For Emmy 2 (1963) jatkoi Ideogramme II tapaan konserttikäytännön rikkomista. Se esitettiin Musiikkinuorison "sabotaasikonsertissa" syksyllä 1963. Konsertti sai nimensä siitä protestimielialasta, joka oli syntynyt nuorten säveltäjien keskuudessa Yleisradion hylättyä tämän Donnerin teoksen viikon ohjelmasta. Hylkäämisen syistä käytiin vilkasta keskustelua. Radion puolelta syyksi esitettiin teoksen valmistumisen myöhästymistä, mutta ilmeinen syy oli myös teoksen radikaalisuus. Happening-vaikutteet tulivat siinä näkyviin selkeästi, olihan Donner edellisenä kesänä ollut järjestämässä happeningejä yhdessä Ken Deweyn ja Terry Rileyn kanssa Suomessa ja Ruotsissa. Happening-taustasta huolimatta teos noudatti ennalta laadittua partituuria, joka on kuvaus konserttitilanteesta kokonaisuudessaan alkaen soittamista edeltävistä valmisteluista ja soittajien ja yleisön sisääntulosta päätyen itse musisointiin. Teoksen aloittaa tenorisaksofonista, pasuunasta, haitarista ja bassosta koostuva yhtye D-duurisoinnulla, jota seuraa sarja masurkkaan, iskelmän ja tangoon viittaavia tonaalisia alluusioita. Muutoin kappale sisältää $\mathrm{mm}$. jakson, jossa laulajat eksperimentoivat äänellä (sisältää sitaatin Cantata Profanasta ja Kinetique-teemasta), minkä jälkeen luodaan hälypilvi. Teoksen viimeisessä osassa soittajat tarttuvat aplodien rytmiin ja muodostavat siitä vielä yhden kokonaisuuden. Kappale "hajoaa" lopuksi siten, että soittajat lähtevät vähitellen pois salista. Tosin osa muusikoista jatkoi musisointia vielä kadullakin. (Heiniö 1988, 38-39; Donner, haastattelu 1994; ks. myös Rautiainen 1992, 45-48.)

\section{Kari Rydman}

Sävellystyönsä ohessa Kari Rydman on tullut tunnetuksi kirjoituksillaan ja radio-ohjelmillaan, sillä erityisesti 1960-luvulla hän oli aktiivinen freelancetoimittaja. Lisäksi hän toimi musiikinopettajana Helsingin yhtenäiskoulussa vuosina 1958-76. Säveltäjänä Rydman on itseoppinut ja koko hänen tuotannossaan näkyy kiinnostus musiikin eri tyylikausiin. Hänen varhaistuotantoonsa kuuluu $\mathrm{mm}$. romanttinen sinfonia, mutta siellä on myös säveltäjän omien sanojen mukaan "vapaammin tonaalisia kokeiluja". Toinen keskeinen piirre Rydmanin varhaistuotannossa on kiinnostus runouteen, erityisesti Hellaakosken runojen säveltämiseen. (Rydman 1994.)

Ensimmäiset selkeät vaikutteet komplisoidumpaan sävelkieleen Rydman sanoo saaneensa Weberniltä, josta on osoituksena mm. laulusarja Kolme laulua Elmer Diktoniuksen sanoihin (1957) (Rydman 1994). Vaikutteet eivät varsinaisesti tule esille sävelkielessä, vaan pikemminkin pyrkimyksessä yhdistää moderni runo ja musiikki: runon monimerkityksisyyttä ja vapaasti kasvavia sekä purkautuvia sisäisiä jännitteitä halutaan korostaa vapaatonaalisin keinoin. Selkeämmin jo sävelkielenkin osalta pyrkimys Webernin varhaislauluja muistuttavaan niukkaeleiseen ja ja aforistiseen ilmaisuun tulee esille laulussa Täällä (1956) Eeva-Liisa Mannerin runoon. (Nuottiesimerkki 2.) 


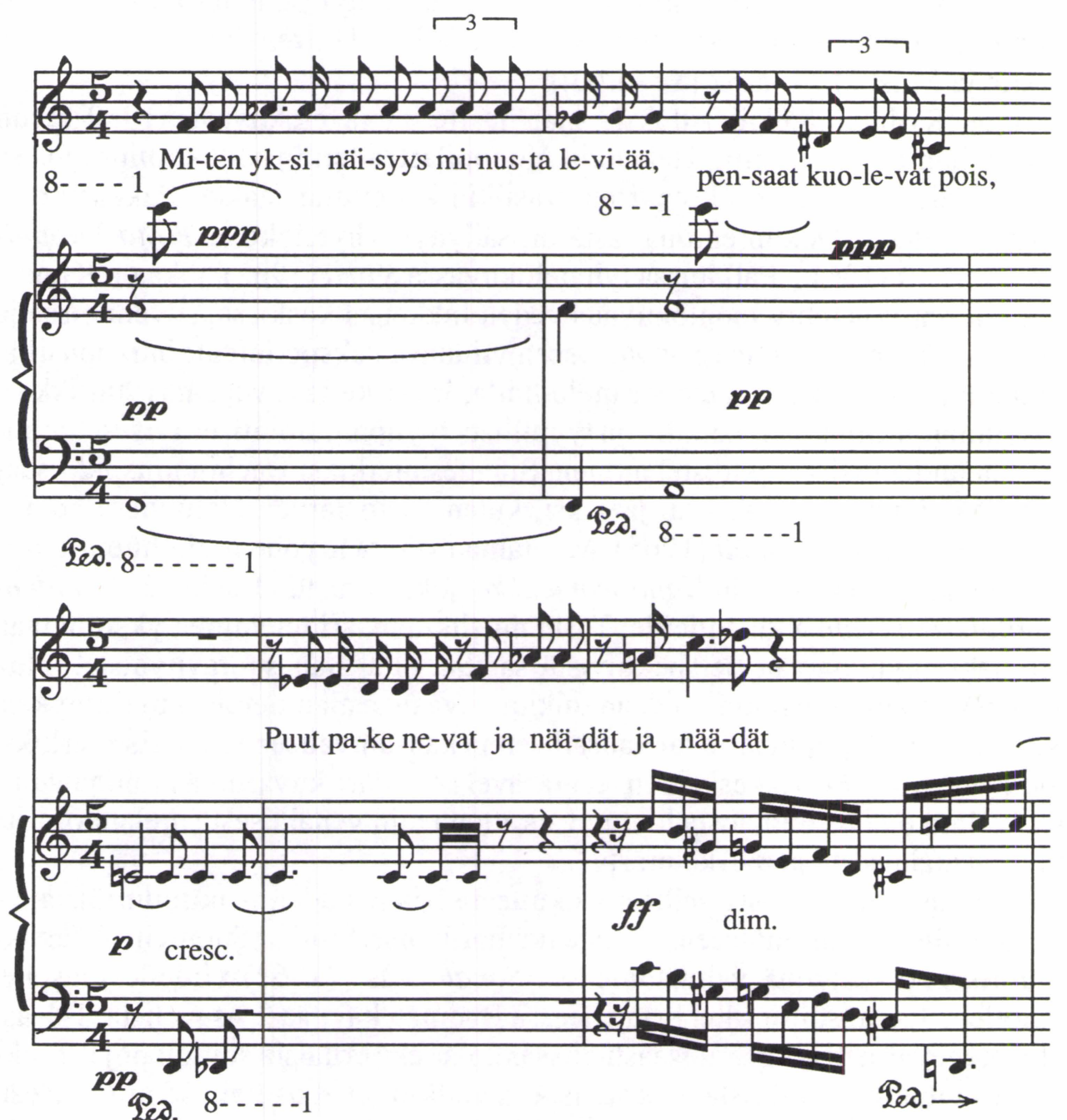

Nuottiesimerkki 2. Kari Rydman: Täällä (1957).

Rydman käyttää 1950-luvun teoksissaan pääasiassa 12-sävelriviä, mutta soveltaa sitä vain muutamassa teoksessa ankarasti. Myöskään sarjallisuus ei saa jalansijaa Rydmanin tuotannossa, poikkeuksena on Pianokvintetto (1959), teoksen osat hän nimeää kuitenkin preludiksi ja fuugaksi. Rydmanin tuotantoa näyttääkin leimaavan ominaisuus, jonka hän myös itse toteaa "sävellyshistoriassaan" (Rydman 1994): "musiikin taustalla on musiikin historia Euroopassa ja muualla ja modernismi on vain sen eräs tulos". Tämä näkyy myös siinä, että 1950-luvun lopusta ja 1960-luvun alusta Rydmanin tuotannosta löytyy myös tonaalisia teoksia. 1960-luvun alussa Rydman ei näytä yhtä aktiivisesti tarttu- 
van eri keinovarojen yhdistämiseen kuin esimerkiksi Donner. Kirjoittaessaan esimerkiksi Kirkko ja Musiikki -lehteen hän keskittyi pikemminkin dodekafonian ja sarjallisuuden esittelyyn kuin sarjallisuuden reaktioilmiöihin. (Ks. Kirkko ja Musiikki 1-5/62 ja 1-4/63. $)^{9}$

Myös Rydmanilla oli sidoksia ajan teatteriin ja elokuvaan. 1950-luvun lopussa hän osallistui $\mathrm{mm}$. Helsingin Ylioppilasteatterin produktioihin, joissa hän teki elektroni- ja konkreettisen musiikin kokeiluita Jaakko Pakkasvirran ohjaajakaudella. Dokumenttina tästä on säilynyt lyhytelokuva Työtä Ylioppilasteatterissa (1961). Palkitussa lyhytelokuvassa Kitka (1962), joka on Kuusamon maisemissa tehty luontokuvaus veden liikkeistä koskissa, suvannoissa ja rannoilla, Rydman käyttää Sonata I:seen viittaavaa eksperimentointia jousilla: glissandoja, lyhyitä, kromaattisia melodioita, 1/4-askelia ja vapaata rytmiikkaa.

Rydmanin elokuvamusiikille on tyypillistä tyyliparodiointi, erityisesti populaari- ja taidemusiikin yhdisteleminen. Siten esimerkiksi Bachin musiikki saadaan kääntymään jenkaksi tai jazziksi, kuten Risto Jarvan elokuvissa Yö vai päivä (1962) ja Onnenpeli (1965). Muutamaa vuotta myöhemmin huomiota ja kritiikkiäkin herättää laulu Kanttorin jenkka, joka perustuu Bachin 3. brandenburgilaiskonserton alkutahdeille. Tosin musiikin määritteleminen yksinomaan parodiaksi nykypäivän perspektiivistä saattaa olla liian suoraviivaista. Yhtä hyvin Rydmanin musiikin voidaan tulkita kuvaavan ajan tietoisia pyrkimyksiä rikkoa taiteen ja populaarin tai kansallisen ja kansainvälisen rajaa. Esimerkiksi elokuvan Yö vai Päivä keskeinen teemasävel Marietta kuvaa tätä moninaisuutta: sävelmä on iskelmä, josta löytyy vaikutteita niin venäläisestä melankoliasta kuin ranskalaisesta jazz-iskelmästä.

Rydmanin tuotannossa selkeät vaikutteet sarjallisuuden reaktioilmiöistä tulevat esille ensimmäiseen "lastenkamarikonserttiin" Suomen Musiikkinuorison tilaustyönä valmistuneessa Sonata I:ssä (1962) viidelle jouselle, pianolle ja lyömäsoittimille. Kappaleessa Rydman käyttää 24-sävelistä, 1/4-askelin etenevää asteikkoa, runsaasti glissandoja sekä erilaisia soittotapoja. Teoksessa osa nuottitekstuurista on graafista, säveltasot ovat osittain summittaisesti osoitettuja ja rytmiikka on vapaa. Mutta Rydman viittaa teoksessa myös omalla tavallaan perinteeseen, josta on osoituksena ennenkaikkea teoksen nimi ja sen kolmiosaisuus. Toisaalta hän rakentaa sävelmateriaalista kolmi- ja nelisointu-

9 1960-luvun alussa Suomen Musiikkinuoriso otti "äänenkannattajakseen" Kirkko ja Musiikki -lehden, josta muodostui ajan merkittävin nykymusiikin esittelijä Suomessa joksikin aikaa. Lehden omalaatuinen linja selittynee lehden karismaattisen päätoimittajan, Lohjan kirkon kanttorin, Antero Lintuniemen, toimituspolitiikalla. Lehti oli syntynyt kilpailijana 1940-luvun loppupuolella Kirkkomusiikki-lehdelle ja kilpailua näiden kahden lehden välillä käytiin 1950-luvulla. Antaessaan palstatilaa nuorille kirjoittajille Lintuniemi sai samalla tarvitsemaansa huomiota lehdelleen. (Lintuniemi, haastattelu 1991.) 
muodostelmia ja toisen osan alussa on selkeä temaattinen 1-viulun melodia, jonka Rydman nimittää cantilene-melodiaksi. Teoksen Rydman on itse nähnyt "nykyisen ajattelutavan positiivisena soveltamisena: kaikki akustiset ainekset ovat taiteellisessa mielessä käyttökelpoisia" (Rydman 1994). Kuitenkin myös Rydman tekee aivan 1960-luvun alussa pitemmälle meneviä kokeiluja esimerkiksi graafisesta notaatiosta, $\mathrm{mm}$. Sarjassa Tuomas Anhavan tekstiin lausujalle ja soitinyhtyeelle, mutta tämä nuottimateriaali on kadonnut. Rydman työstää pääosin samaa Anhavan tekstiä 1970-luvulla Sarjassa Tuomas Anhavan testeihin lausujalle ja sinfoniaorkesterille (1975).

Sonatan I:n jälkeen syntyi jatkona Sonata II ja seuravana vuonna Sonatat $I I I-V$. Erikoisuutena Sonata $I V$ :ssa on sähkökitara, jota Rydman käyttää myös myöhemmin teoksissaan. Sonata $V$ :ssä, joka kuitenkin jäi vain suunnitelman tasolle, Rydman tekee tilakokeiluja: eri soitinyhtyeet oli määrä sijoittaa eri puolelle salia ja miksata kovaäänisten kautta ulos. (Rydman 1994.)

Donnerin tapaan myös Rydman yhdistää modernin kuorolaulun keinoja teoksessa Dona Nobis Pacem (1963) sekakuorolle, bassolle ja lyömäsoitinyhtyeelle. Teoksessa Rydman etsii sointivärejä rikkomalla tekstin tavuiksi ja sijoittamalla sen eri ääniin keinovarojen ulottuessa kuiskauksesta laulamiseen. Kappale sisältää myös selvän tonaalisen viittauksen: osan yhdestä Beethovenin IX sinfonian kuorofinaalin teemasta. (Rydman 1994.) Sitaattien ja alluusioiden käyttö tuleekin varsin pian keskeiseksi Rydmanin tyylissä. Vuonna 1963 syntyy teos, joka kuitenkin viittaa vahvasti 1960-luvun alun avantgardeen Euroopassa. Teos on Serenade a Djamila Boupacha (1963), jonka inspiroijana oli Simone de Beauvoirin kirja Algerian sodassa kidutetusta tytöstä. Teos viittaa ennenkaikkea Pendereckiin ja Ligetiin, kuten myös Heiniö $(1988,29)$ on todennut. Teoksen rakenne vaihtelee klustereiden ja glissandojen dynamiikaltaan vaihtelevasta kentästä rikaskuvioiseen ja rikassointiseen kudokseen, jossa lyömäsoittimet ovat etusijalla. Sitaatteja tai alluusioita ei Rydman tähän teokseen sisällytä. Kuitenkin toivomuksena on, että puhaltajien ja erityisesti klarinetin soittajien tulisi olla jazz-muusikoita. Teoksessa onkin jakso (nuottiesimerkki 3), jossa puhaltimilla muodostuu lähinnä ns. "kolmannen linjan" jazziin viittaava kudos. (Ks. esim. The New Grove Dictionary of Jazz 1988, 428.)

Taide- ja populaarimusiikin yhdisteleminen, mikä oli näkyvissä Rydmanin elokuvamusiikissa, tulee esille erityisesti Jousikvartetoissa II-IV (1963-64), mutta näissä hän käyttää lyhyitä sitaatteja ja alluusioita. Erityisesti 3. ja 4. kvartetossa Rydman käyttää viittaustekniikkaa, hän liittää tonaaliset viittaukset moderniin kontekstiin (ks. Heiniö 1988, 17-18.) Kolmannessa jousikvartetossa, aleatorisen tekstuurin keskellä on suora sitaatti Mozartin Es-duurikaksoiskonsertosta. Neljäs jousikvartetto on sitaateista ja alluusioista rakennettu kollaasi, jossa vaikutteet ulottuvat Bartokista, wieniläisvalssin kautta boogie-woogieen. 

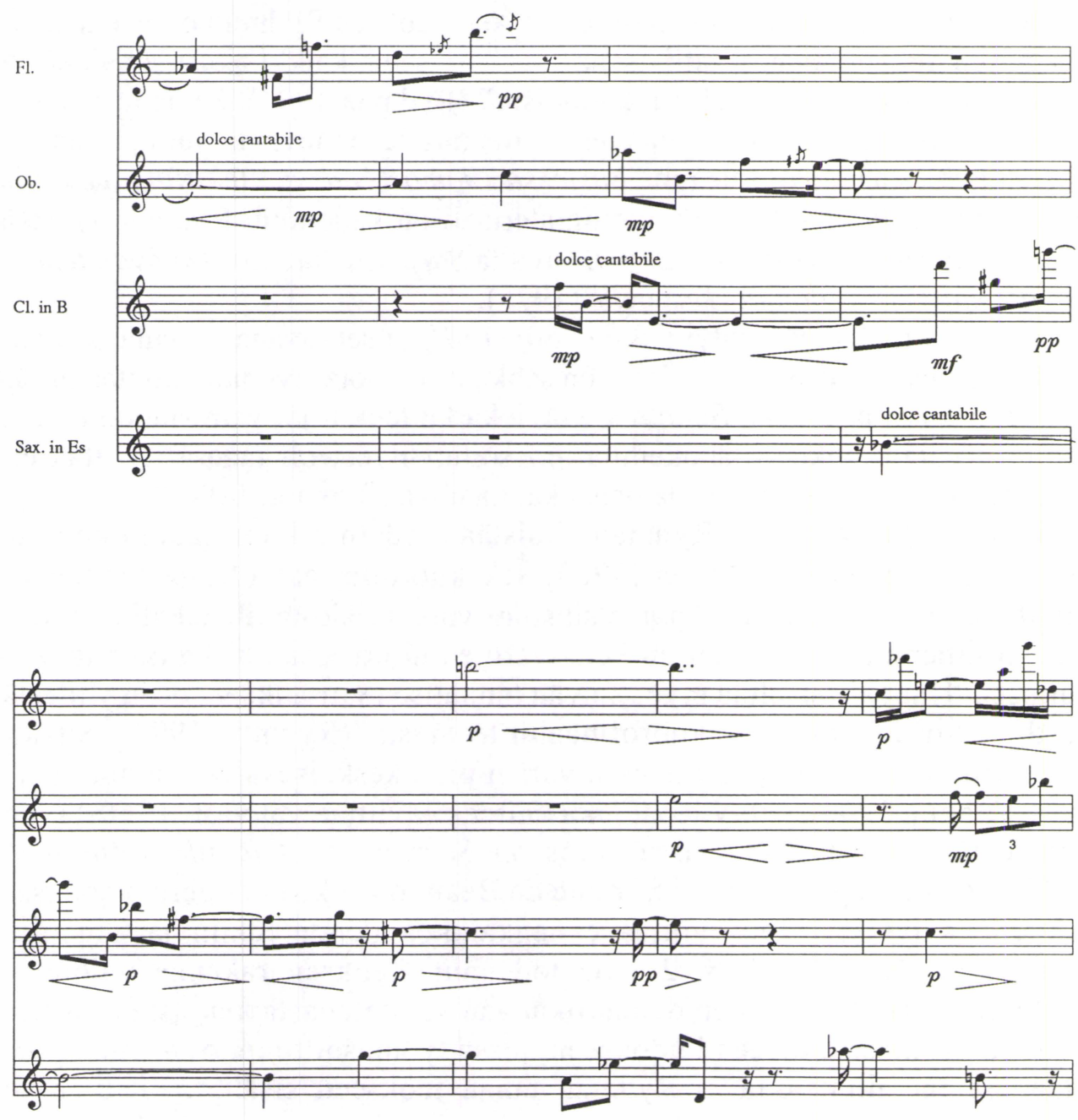

Nuottiesimerkki 3. Kari Rydman: Sérénade pour Djamila Boupacha.

\section{Avantgardesta populaarimusiikkiin}

Yhteistä Otto Donnerin ja Kari Rydmanin toiminnalle 1960-luvun alkuvuosina on laaja-alaisuus: heidän tuotantonsa käsittää niin taidemusiikkia ja jazzia kuin teatteri- ja elokuvamusiikkiakin. Molemmat säveltäjät pyrkivät omalla tavallaan etsimään ja rikkomaan rajoja musiikissa yhdistämällä toisiinsa eri musiikkityylejä ja -vaikutteita. Siinä missä Donner on valmis kokeilemaan monilla 1950-luvun modernismin keinovaroilla ja lähtee lisäksi aktiivisesti etsimään musiikin rajoja, pysyy Rydman omassa tuotannossaan pääasiassa 
tradition viitoittamilla linjoilla. Kuitenkin molemmat säveltäjät tekevät kokeiluja sekä elektroni- että konkreettisen musiikin parissa ja käyttävät esimerkiksi äänentoistolaitteita konserttitilanteessa. Suomalaisen 1960-luvun avantgarden luonteenomaisimmaksi piirteeksi voisikin luonnehtia innovatiivisuutta, uuden sävelilmaisun etsimistä. Innovatiivisuuden syynä ja seurauksena on epäilemättä säveltäjien laaja toimintakenttä, mutta yhtä hyvin se voidaan tulkita osoitukseksi tietoisesta protestista vallitsevaa taidemusiikin ilmapiiriä ja musiikkiestetiikkaa kohtaan. Osaltaan tästä halusta laajentaa suomalaisen taidemusiikin liikkumatilaa kertovat myös Kirkko ja Musiikki -lehtien artikkelit 1960-luvun alussa.

Donnerin tuotannossa yhdisteleminen ulottuu muuhunkin kuin musiikilliseen materiaaliin, onhan esimerkiksi Cantata Profanaan leikattu eri runoilijoiden tekstejä. Tästä teoksesta lähtien Donnerin tyylille näyttääkin olevan ominaista erilaisten rakenne-elementtien yhdistäminen sekä eri ainesten yhtäaikaisuus ja kerrostaminen, polyfonia. Selkeimmillään kerrostaminen tulee ilmi esimerkiksi Donnerin yhdessä Folke Raben ja Jan Barkin kanssa ideoimassa teoksessa Siamfoni (1964), johon kuuluu kuuden eri säveltäjän teokset, joista kaksi esitetään kerrallaan. ${ }^{10}$ Lisäksi tyypillistä Donnerin teoksille 1960-luvun alussa näyttää olevan polyfonia -ajatuksen liittäminen muihin taidemuotoihin, onhan esimerkiksi Ideogramme II:ssa ympäristönä taidenäyttely. Donnerin tyylistä löytyy myös piirteitä montaasista. Tästä on esimerkkinä Ruutsalon lyhytelokuva Two Chickens (1963), jonka musiikki rakentuu lyhyistä pätkistä musiikkia, puhetta ja käsiteltyä ääntä.

Rydman pitäytyy omassa tyylissään pikemminkin eri musiikkityylien yhdistämisessä kuin rakentaa taiteidenvälisiä siltoja. Hänelle esimerkiksi 1950-luvun modernismin keinovarat ovat mahdollisuuksia muiden joukossa (Rydman 1994). Vaikka varsinaisesti vasta Jousikvartetoissa Rydman alkaa luoda selkeitä vastakohtia viittausten - sitaattien ja alluusioiden - avulla, on vastaavaa tyyliä havaittavissa myös hänen aiemmissa teoksissaan. Jousikvartetoista lähtien vastakkainasettelu tulee kuitenkin selkeästi esille. Myös tonaalisuuden ja atonaalisuuden vastakohtaisuus näyttää hänelle olevan useammin keinovara kuin Donnerille. Kuitenkin myös Donner rakentaa esimerkiksi "ironisessa sinfoniassaan" Moonspring, or Aufforderung zum..., or Symphony No. 1 vastaavanlaista jännitettä. Teos on kollaasi, joka rakentuu pääasiassa lainatulle materiaalille. Sitaatteja on mm. Mozartilta, Weberniltä, Pendereckiltä, Kokkoselta ja Beatlesilta. Keskeisessä asemassa teoksessa on Veron Duken kappale Autumn in New York.. Vaikka teoksesta löytyy Donnerille ominaista musiikillisen materiaalin kerrostamista, näyttää juuri kontrastin luominen olevan siinä keskeistä. (Ks. myös Heiniö 1988, 39-41.)

10 Teoksen säveltäjinä olivat Lars Werner, Erkki Salmenhaara, Arne Mellnäs, Erkki Kureniemi, Otto Donner ja Jan Bark. Teos esitettiin Tukholman Modernin taiteen museossa vuonna 1964 . 
Donnerin ironinen sinfonia kuten Rydmanin tyyliparodiatkin voidaan tulkita osaltaan avantgardeen liittyväksi "etsinnäksi", mutta samalla ne kuvaavat myös ajankohdan taideilmaston uutta piirrettä: eksperimentoinnin rinnalle alkaa tulla kantaaottavuus ja keskustelu saa poliittista leimaa. Tähän liittyy osaltaan värikäs keskustelu populaarimusiikista ja sen asemasta ja arvostamisesta, joka alkoi vuoden 1964 aikana. Erityisesti Kari Rydman ja Kaj Chydenius kritisoivat taidemusiikin hallitsevuutta ainoana "hyväksyttynä" musiikin alueena ja toisaalta vallitsevaa taidemusiikin estetiikkaa, jonka perusteella "hyvä" ja "huono" musiikki määriteltiin. Vastaansa he saivat vanhemman sukupolven, mm. Joonas Kokkosen ja Seppo Nummen. Tuloksena oli kärkkäitä lehtikeskusteluita, jotka äärimmillään kiteytyivät kiistelyyn väittämästä 'hyvä iskelmä on parempi kuin huono sinfonia" (ks. esim. Rydman 1962). Toisaalta taide- ja populaarimusiikin yhdistämisestä muodostui yksi keskeinen piirre nuorten säveltäjien tuotantoon, kuten edellä on tullut esille. (Populaarimusiikkia koskevasta keskustelusta ks. Rautianen 1992, 57-76.)

\section{Avantgarde ja suomalainen taidejärjestelmä 1960-luvulla}

Kun toimittaja nykypäivänä perää säveltäjältä syitä siihen, miksi tämä ei halua kohahduttaa (esim. Välinoro 1994), moni lukija tuskin tietää, millaisia merkityksiä sana "kohahduttaminen" sai 1960-luvun alussa avantgarden ympärillä käydyssä keskustelussa. Näitä merkityksiä tuo sana kantaa mielestäni mukanaan yhä vielä suomalaisessa musiikkikeskustelussa. Merkityssisältöjen samoin kuin koko ilmiön syvempi ymmärtäminen on mahdollista nähdäkseni siten, että avantgardea tarkastellaan laajemmin osana suomalaista kulttuurielämää 1960-luvun alussa. Yhtä oikeaa, kaikenkattavaa tai selittävää näkökulmaa ei varmasti ole olemassa, joten lienee tarkoituksenmukaisempaa tarkastella liikettä useista lähtökohdista käsin.

1960-luvun alun musiikin avantgardea kritisoitiin ajankohtana ja myös jälkeenpäin muoti-ilmiöksi ja sensaation hakemiseksi. Kritiikissä epäiltiin myös nuorten säveltäjien taitoja ja kykyjä. Suhtautumista musiikin kentän kapinallisiin kuvaa hyvin musiikkilehti Rondon ensimmäisessä numerossa julkaistu kiertokysely Avant-gardismi - rappiota vai tulevaisuuden musiikkia. Siinä musiikin ja kulttuurielämän vaikuttajat pohtivat avantgarden merkitystä. Rolf Nevanlinna tiivisti kritisoijien mielipiteen musiikin senhetkisistä uudistajista, sillä hänen mielestään "riehuu vakavaan uudistukseen pyrkivien ympärillä tavanomainen kuvainkaatajien kirjava lauma" (Nevanlinna 1963). (Avantgarden kritiikistä enemmän ks. Rautiainen 1992, 32-54.) Tämäntyyliset argumentit näyttävät sinänsä olevan tyypillisiä uutta musiikkia koskevalle keskustelulle, kuten myös Heiniö (1984, 310-312) on todennut. Kuitenkaan modernismi ja avantgarde eivät herättäneet keskustelua vain musiikkielämän piirissä 1960-luvun alussa. Kuten edellä on useaan otteeseen tullut ilmi, oli nuorilla 
säveltäjillä yhteyksiä myös muihin taiteenaloihin, joissa käytiin vastaavaa keskustelua. Ensimmäisenä kiinnostus uusia ilmaisumuotoja kohtaan, mikä nyt oli siis voimakkaampaa kuin 1920-luvun modernismissa, syntyi lyyrikoiden piirissä, jotka 1940-luvun loppupuolelta lähtien kiinnostuivat Euroopassa jo paikkansa vakiinnuttaneesta modernista runosta. Nuoren lyyrikkopolven kiinnostus kohdistui "kielen vapauttamiseen" ja ennenkaikkea "muodon vallankumoukseen": perinnäisistä muotoa rajoittavista tekijöistä haluttiin irtautua. 1950-luku olikin perusteellista runon ilmaisukeinojen ja sisällön uudelleenarvioimista. Käytännössä tämä merkitsi vapaasti käytettyä rytmiä, perinteisestä loppusoinnullisuudesta luopumista ja assosiaatioketjujen käyttöä fraasien asemasta. Mutta myös subjektiivista todellisuuskäsitystä haluttiin korostaa: assosiaatioketjut tarjosivat useita tulkintamahdollisuuksia ja tällä tavalla lukijan osuus tuli keskeiseksi. Runon tuli saada uusia ulottuvuuksia lukijan kokemusmaailman mukaan. Lisäksi modernin runon tehtävänä nähtiin olevan totunnaisten ajatuskuvioiden murtaminen, ei pelkästään ajatusten välittäminen. Siten samalla kun modernin runon ympärillä käyty keskustelu synnytti kiinnostuksen kaikkiin ja kaikenlaisiin kielen keinoihin, subjektiivisuuden korostamisesta muodostui yksi seuraavan vuosikymmenen runouden lähtökohdista, kun yksilön yhteiskunnallista ja poliittista tietoisuutta alettiin korostaa. (Kunnas 1981, 139-147 ja 192-197.)

Samoin kuvataiteen piirissä syntyi 1950-luvun loppupuolella "avoin taide" -käsite. Impulssit tähän tulivat Ruotsista, jossa erityisesti Modernin taiteen museo saattoi yhteen perinteisiä ja uusia taidenäkemyksiä. Uutta myös kuvataiteessa oli subjektiivisen taidenäkemyksen puolestapuhuminen: taiteen kokijan oma käsitys nousi keskeiseksi ja katsojasta tuli osa taideteosta. Esteettiset arvot joutuivat uudelleenarvioinnin kohteeksi. Keskustelu konkretismista tai ekspressionismista väistyi ja alaa valtasi asenne jota mm. Lintinen (1979) on kuvannut "välinpitämättömyyden estetiikaksi". Asenteen synnyttäjänä Lintinen näkee keskeisesti olevan John Cagen ajatukset, joille oli ominaista "koko maailman kokeminen taiteena": huomio kiinnitettiin arkielämän tapahtumiin. Cagen ajatukset koettiin helposti provokaationa, sillä esimerkiksi musiikissa Cagen ajattelu merkitsi perinteisen musiikkikäsityksen ja porvarillisen musiikki-instituution hylkäämistä. 1960-luvun taiteen kokeilujen, esimerkiksi happeningin, taustalta löytyykin keskeisesti "hätkähdyttämisen" periaate: juhlallinen "Taide" haluttiin palauttaa arkipäivään.

Peter Bürger (1984, 20-27 ja 47-54) on tulkinnut vuosisadan alun avantgarde-liikettä porvarillisen taideinstituution itsekritiikkinä. Huomattava kuitenkin on, että Bürgerille taiteen autonominen asema merkitsee mahdollisuutta kritisoida (porvarillista) yhteiskuntaa, ts. hän näkee taiteella olevan yhteiskunnallisen muutostehtävän. (ks. Siivonen 1992, 38). Teoriaa ei ole mahdollista tarkastella kokonaisuudessaan tässä yhteydessä, mutta suhteutan sitä joiltakin osin käsittelemääni aineistoon. 
Bürgerin (1984, 22-23) mukaan eurooppalaisten avantgarde-liikkeiden, joista hän käyttää nimitystä historiallinen avantgarde, keskeinen tehtävä oli kyseenalaistaa porvarillisessa yhteiskunnassa vallitsevaa taiteen status. Avantgardeliikkeet pyrkivät lakkauttamaan autonomisen porvarillisen taideinstituution ja palauttamaan sen elämänkäytäntöön hylkäämällä koko taideinstituution ja kääntymällä äärimmillään sitä vastaan. Erityisesti kritiikin kohteena oli estetismi, joka Bürger pitää autonomisen taideinstituution kehityksen huipentumana. Keskeinen ero avantgarde-liikkeiden ja modernismin välillä on Bürgerin mielestä siinä, että modernismi tuli lähelle klassismin taiteellisia ideaaleja. Korostaessaan taideteosta ja materiaalista muotoa modernismi painottaa yksilöllisyyttä ja yksilön tulkintaa ja hyväksyy näin yhteiskunnallisen modernisaation eriytymisen. (Bürger 1991, 52, referoinut Siivonen 1992, 45.) Tosin tämä näkökulma on herättänyt myös kritiikkiä (esim. Siivonen 1992, 45).

Avantgarden tuomio ei perustunut niinkään taideteosten sisältöön kuin niiden funktioon; se hyväksyi taiteen estetismin kieltäytymisen päärärationaalisesta arjesta, mutta kritisoi käsitystä, jonka mukaan taideteos olisi sinällään päämäärä. Avantgarde vaati taiteen ja elämänkäytännön yhdistämistä: 'käytäntö voi olla esteettistä ja taide käytännöllistä" (Bürger 1984, 51). Tästä näkemyksestä ja etenkin siitä kuinka "toivottavaa" taiteen ja elämänkäytännön yhdistäminen olisi, on myös kiistelty (esim. Siivonen 1992, 42-43). Taiteen ja elämänkäytännön yhdistämisessä historiallinen avantgarde ei kuitenkaan onnistunut, taideinstituutio on edelleen autonominen, mutta Bürgerin mielestä avantgardeliike sai aikaan tietyn vapautumisen ja itsetietoisuuden voimistumisen. Sen jälkeen millään tyylisuunnalla ei voi olla enää selvää eikä yleistä pätevyyttä. (Ks. myös Kotkavirta 1991.)

Bürgerin luonnehdinnoista voidaan löytää vastaavuutta 1960-luvun alun suomalaisen musiikin avantgarden piirteisiin. Kuitenkin jälleen tulee muistaa historiallinen kehitys Suomen suhteen: voimakkain modernismin aalto ja avantgarde tulivat lähes yhtäaikaa 1950-luvun lopulla. Selkeimmin piirteitä porvarillisen taideinstituution kritiikistä tulee esille Otto Donnerin tuotannossa 1960-luvun alussa. Keskeistähän useille hänen teoksilleen tuona aikana on perinteisen konserttitilanteen "vapauttaminen": yleisön ja esittäjien välinen raja tulee uudelleenarvioinnin kohteeksi. Toisaalta Otto Donnerin teoksille on tuolloin tyypillistä myös toinen avantgarden perusominaisuus fragmentaarisuus: materiaali irrotetaan kokonaisuudesta, eristetään ja muutetaan fragmenteiksi (ks. Siivonen 1992, 44). Toisaalta avantgardeliikkeen seurauksia tarkasteltaessa Bürger näyttää päätyvän samantyyliseen johtopäätökseen kuin Mikko Heiniö (1988), joka on tutkinut suomalaista 1960-luvun jälkeen syntynyttä musiikkia. "Lastenkamarikonserteista" päädytään pluralismiin, monien tyylien rinnakkaisuuteen. Mutta huomattava on, että suuntaus jää yhdeksi linjaksi taidemusiikin piirissä, eikä suomalainen taidemusiikki avantgarden myötä moniarvoistunut. 
Vallankumoukset eivät näytä olevan tuontitavaraa: suomalaiselle 1960-luvun alun avantgarde-liikkeelle on löydettävissä myös perustelunsa suomalaisen taidejärjestelmän piirteistä. Keskeisin niistä on mielestäni modernismin ja avantgarden ajallinen viive Suomen osalta: se eurooppalainen keskustelu, jota taiteen piirissä oli käyty vuosisadan vaihteesta alkaen, tavoitti Suomen varsin myöhään, mutta tuli sitten hyvin voimakkaana aaltona. Samaan ajanjaksoon ajoittuu myös hyvin nopea yhteiskuntarakenteen muutos. Kuitenkaan agraarisiin arvoihin sitoutuneessa yhteiskunnassa ei löytynyt kaikupohjaa kovin helposti uusille voimakkaana tulleille ajatussuuntauksille. Tuloksena oli konflikti, joka tuli parhaiten näkyviin kirjallisuuden piirissä ns. kirjasotina. Ilmiö oli tuttu jo sotaa edeltävältä ajalta, mutta eniten julkisuutta saaneet kirjasodat käytiin 1960-luvulla (ks. esim Sevänen 1994, 138-146.) Armisen mukaan (1989, 60-62) kulttuurisodat ovat korostetusti suomalainen ilmiö. Niiden taustalla on suomalaiselle julkisuudelle ominainen piirre: eheys. Julkisuudelle on asetettu vaatimus olla sopusoinnussa kansallisen arvojärjestelmän kanssa. Sen perusteella kaikilla on ollut sanansa sanottavanaan kaikkeen. Kuitenkaan eheys ei ole merkinnyt ristiriidattomuutta: keskusjulkisuudesta on käyty jatkuvaa taistelua. Valtasuhteet ovat olleet korostetusti esillä julkisuudessa ja eriytyneiden osajulkisuuksien kehittyminen on ollut hidasta. Siten kansallinen yhtenäisyys on ollut keskusjulkisuuden päämäärä, jota uudistusliikkeet ovat koetelleet. Uudistusliikkeiden sietäminen on puolestaan riippunut siitä, kuinka paljon ristiriitoja taidejärjestelmä on kestänyt. Sillä vaikka taidejärjestelmät ovat ylläpitäneet ja muokanneet kansallista arvojärjestelmää, ei niiden sisällä ole läheskään aina esiintynyt yhtenäistä arvomaailmaa. Seväsen $(1994,385)$ mukaan esimerkiksi 1920- ja 30-luvulla suomalaisessa kirjallisuusinstituutioissa ristiriitoja ilmeni eri kieliryhmien, oikeiston ja vasemmiston, taiteen ja viihteen ja toisaalta taiteen ja kansanvalistuksellisten näkökulmien välillä.

Nähdäkseni kyse oli paljolti sietämisestä myös musiikin avantgarde-liikkeen kohdalla. Ajankohdan lehtikeskustelusta ei löydä juuri viitteitä, joita voitaisiin tulkita suoranaisesti ideologiseksi tai moraaliseksi valvonnaksi. Keskustelussa pohdittiin pääasiassa sitä, onko nuorten säveltäjien teokset musiikkia vai ei ja onko avantgarde leikkiä vai merkki musiikin kriisistä tai rappiosta. Keskustelu koski siis yksiomaan musiikillista ilmaisua, mutta tietyt keskustelun piirteet herättävät mielenkiintoa. Erityisesti Rondon kiertokyselyssä "Avantgardismi - rappiota vai tulevaisuuden musiikkia" näyttää toteutuvan Armisen (1989, 60-64) luonnehdinta eräästä suomalaisen julkisuuden piirteestä: kaikilla on sanottavansa kaikkeen. Kyselyssä yhteiskuntaelämän vaikuttajat, korkeimpana ehkä Rolf Nevanlinna kertovat käsityksiään avantgardesta. Vaikka kyselyssä olivat myös Otto Donnerin ja Erkki Salmenhaaran kannanotot, näyttää kysymyksenasettelun takana olevan 'konsensuksen ihanne", tavoitteena on saavuttaa jonkinlainen julkinen mielipide ilmiön puolesta tai vastaan. Toisaalta kaksijakoisuus "rappiota vai tulevaisuuden musiikkia" näyttää olevan tyypillistä ajankohdan avantgarde-keskustelulle yleisestikin (ks. Rautianen 
1992, 31-51). Musiikin piirissä käytävälle keskustelulle se ei liene tavatonta nykypäivänäkään, mutta ajankohdan yleiselle kulttuuri-ilmapiirille se oli leimaa-antavaa. Kuitenkin voi kysyä, missä määrin julkisuudessa käyty keskustelu on osoitus pyrkimyksestä saavuttaa yleisesti hyväksytyt normit taiteen tekemiselle.

Seväsen (1991a, 173) mukaan nykyaikaisen taidejärjestelmän tunnusmerkki on ideologinen pluralismi: järjestelmän sisällä hyväksytään varsin laaja ideologinen ja tyylillinen moninaisuus. Tämä ei näytä toteutuneen juurikaan 1960-luvun alun Suomessa. Toisaalta yksi hyvin yksinkertainenkin selitys on mahdollista antaa: maaperää avantgarden tai aina edes modernismin vastaanottamiseen ei ollut.

Taidemusiikin piirissä nuoren ja vanhemman säveltäjäpolven ristiriita tuli avantgarden myötä ylitsepääsemättömäksi. Nuoret säveltäjät näyttävät tässä rikkoneen taidemusiikin kentän pelisääntöjä myös hyvin perustavaa laatua olevalla tavalla, jos tarina siitä, että Einar Englund lopetti säveltämisen joksikin aikaa siitä syystä, että Folke Rabe jakoi hänelle oman sävellyksensä yhtenä osana mandariineja, pitää paikkaansa. Oli syy mikä tahansa - luultavasti Englundin kohdalla pitempiaikainen erimielisyys avantgardepolven kanssa kertoo tarina jo sinällään jotakin olennaista ajan kulttuurimurroksesta, joka oli luonteeltaan raju ja väkivaltainen. Yhä selkeämmin murroksen luonne alkoi tulla esille sitten, kun taiteen ja viihteen välinen rajanveto tuli keskustelun kohteeksi ja taiteiden piirissä vallitseva kokeilumieli sai rinnalleen aatteellisia painotuksia.

\section{Lähteet}

\section{Kirjallisuus}

Arminen, Ilkka 1989. Juhannustansseista jumalan teatteriin - suomalainen julkisuus ja kulttuurisodat. Tutkijaliiton julkaisusarja 58. Jyväskylä.

Barthes, Roland 1987. Image-music-text. Fontana Press. Glasgow.

Bürger, Peter 1984. Theory of the Avant-Garde. Orig. Theorie der Avantgarde (1974). Translated by Michael Shaw. Minneapolis.

Dickie, George 1981. Estetiikka. Orig. Aesthetics. An Introduction (1971). Suomentanut Heikki Kannisto. Hämeenlinna.

Garfinkel Harald 1967. Studies in Ethnomethodology. Prentice-Hall.

Heiniö, Mikko 1984. Innovaation ja tradition idea. Näkökulma aikamme suomalaisten säveltäjien musiikkifilosofiaan. Acta Musicologia Fennica 14. Helsinki.

Heiniö, Mikko 1986. 12-säveltekniikan aika. Dodekafonian ja sarjallisuuden reseptio ja Suomen luova säveltaide 1950-luvulta 1960-luvun puoliväliin. Musiikki 3-4/1986. 
Heiniö, Mikko 1988. Lastenkamarikonserteista pluralismiin. Postmoderneja piirteitä uudessa suomalaisessa musiikissa. Musiikki 1-2/1988.

Heiniö, Mikko 1991. Tekniikka ja tyyli - suomalaisen musiikin innovaatioita 1945-1990. Teoksessa Klang - uusin musiikki, toim. Lauri Otonkoski. Jyväskylä.

Heiniö, Mikko 1992. Kontekstualisoiminen taidemusiikin tutkimuksessa. Musiikki 1/1992.

Jalkanen, Pekka 1989. Alaska, Bombay ja Billy-Boy. Jazzkulttuurin murros Helsingissä 1920-luvulla. Suomen etnomusikologisen seuran julkaisuja 2. Helsinki.

Karkama, Pertti 1991. Subjektin ongelma Goerg Lukacsin kirjallisuusteoriassa. Teoksessa Taide modernissa maailmassa, toim. Erkki Sevänen, Liisa Saariluoma ja Risto Turunen. Helsinki.

Kotkavirta, Jussi 1991. Katkoksia ja jatkuvuuksia modernissa taideinstituutiossa: Peter Bürger ja Jürgen Habermas. Teoksessa Taide modernissa maailmassa, toim. Erkki Sevänen, Liisa Saariluoma ja Risto Turunen. Helsinki.

Kunnas, Maria-Liisa 1981. Muodon vallankumous. Modernismin tulo suomenkieliseen lyriikkaan 1945-1959. Pieksämäki.

Kurkela, Vesa 1986. Tanhuten valistukseen. Musiikkivalistus ja perinnetyö Suomen Demokraattisessa Nuorisoliitossa. Työväenmusiikki-instituutin julkaisuja 5. Helsinki.

Kurkela, Vesa 1991. Etnomusikologian historiattomuus ja nykyajan haasteet. Kansanmusiikin tutkimus, metodologian opas, toim. Pirkko Moisala. Helsinki.

Lepistö, Vappu 1991. Kuvataiteilija taidemaailmassa. Tapaustutkimus kuvataiteellisen toiminnan sosiaalipsykologisista merkityksistä. Tutkijaliitto.

Maegaard, Jan 1984. Musiikin modernismi 1945-1962. Helsinki.

Moisala, Pirkko 1994. Musiikki sukupuolen kautta tulkittuna - esimerkkejä sukupuolistavasta musiikintutkimuksesta. Musiikki 3/1994.

Mäkelä, Tomi 1990. Kohdelähtöisyyttä ja tyyppikeskeisyyttä. Musiikki $1 / 1990$.

The New Grove Dictionary of Jazz. Volume Two, L-R. Edited by Barry Kernfeld. Macmillan Press Limited, London 1988.

Richardson, John 1994. Feminiinisyyden ja maskuliinisuuden androgyyninen avioliitto Philip Glassin musiikissa. Musiikki 3/1994

Sepänmaa, Yrjö 1991. Institutionaalinen taideteoria. Teoksessa Taide modernissa maailmassa, toim. Erkki Sevänen, Liisa Saariluoma ja Risto Turunen. Helsinki

Sevänen, Erkki 1991a. Nikol-koulukunnan teoria taiteesta sosiaalisena järjestelmänä. Teoksessa Taide modernissa maailmassa, toim. Erkki Sevänen, Liisa Saariluoma ja Risto Turunen. Helsinki.

Sevänen, Erkki 1991b. Metodologiset jälkisanat. Teoksessa Taide modernissa maailmassa, toim. Erkki Sevänen, Liisa Saariluoma ja Risto Turunen. Helsinki. 
Sevänen Erkki 1994. Vapauden rajat. Kirjallisuuden tuotannon ja välityksen yhteiskunnallinen sääntely Suomessa vuosina 1918-1939. Suomalaisen Kirjallisuuden Seuran toimituksia 612. Helsinki.

Shepherd, John 1991. Music as social text. Polity Press.

Siivonen, Timo 1992. Avantgarde ja postmodernismi. Itsekritiikki ja radikalisoituminen modernissa taideinstituutiossa. Nykykulttuurin tutkimusyksikön julkaisuja 33. Jyväskylä.

Tuomikoski-Leskelä, Paula 1977. Taide ja politiikka. Kansanedustuslaitoksen suhtautuminen taiteen edistämiseen Suomessa. Pohjolan Sanomat.

Tuominen, Marja 1990. 'Me kaikki ollaan sotilaitten lapsia'. Sukupolvihegemonian kriisi 1960-luvun suomalaisessa kulttuurissa. Helsinki.

Wallner, Bo 1968. Vår tids musik i Norden. Från 20-tal till 60-tall. Publikationer utgivna av kungl. musikaliska akademien med musikhögskolan, nr. 5.

\section{Painamattomat lähteet}

Rautiainen, Tarja 1992. Modernismista massakulttuurikeskusteluun: musiikkiradikalismi ja suomalainen taidemusiikki. Kansanperinteen, erityisesti kansanmusiikin pro gradu -tutkielma. Tampereen yliopisto.

Rydman, Kari 1994. Sävellyshistoriaa.

\section{Lehtiartikkelit}

Chydenius, Kaj. Sarjallisen musiikin aika on ohi! Kirkko ja Musiikki 1961: 7-8.

Donner, Otto 1963. Musiken bör ha publik. Huvudstadsbladet 13.5.1964.

Hankiranta, Raimo 1963. Nykymusiikkia - veron uhallakin. Ylioppilaslehti 25.10.1963.

Lintinen, Jaakko 1979. Astronautteja, rajanylittäjiä, säpinää. Esteettisiä kokeiluja ja avantgardismia 60-luvulta. Taide 1979:5.

Nevanlinna, Rolf 1963. Rappiota vai tulevaisuuden musiikki. Rondo 1963:1. Rydman, Kari 1959. Modernismi ja avantgardismi. Ylioppilaslehti 15.5.1959. Rydman, Kari 1969. Sairas musiikkimme. Ylioppilaslehti 6.5.1960.

Rydman 1964. Kevyen musiikin ylistys. Aikalainen 1964: 1.

Saunio, Ilpo 1962. Graafinen musiikki II. Kirkko ja Musiikki 1962: 9.

Välinoro, Anne 1994. Eikö säveltäjä osaa enää kohauttaa?. Aamulehti 9.7.1994. 
Haastattelut

Tarja Rautiaisen kokoelmat

Bandler, Vivica 1994. Helsingissä 13.9. 1994.

Donner, Otto 1994. Helsingissä 17.8. 1994.

Chydenius, Kaj 1992. Helsingissä 13.5.1992.

Lintuniemi, Raimo 1991. Haastattelu Helsingissä 20.11. 1991.

Lyhytelokuvat

Eino Ruutsalon arkisto

Kineettisiä kuvia / Kinetic Pictures 1962.

Annecy 1963.

Kaksi kanaa / Two Chickens 1963.

Kotka 1962.

Suomen elokuva-arkisto.

Työtä Ylioppilasteatterissa 1962.

Kitka 1962.

Yö vai päivä 1962.

Onnenpeli 1965. 